\title{
Impacts of land use/land cover and climate changes on soil erosion in Muga watershed, Upper Blue Nile basin (Abay), Ethiopia
}

Tatek Belay ${ }^{1,2^{*}}$ (1) and Daniel Ayalew Mengistu ${ }^{2,3}$

\begin{abstract}
Background: Soil erosion is one of the major threats in the Ethiopian highlands. In this study, soil erosion in the Muga watershed of the Upper Blue Nile Basin (Abay) under historical and future climate and land use/land cover (LULC) change was assessed. Future LULC was predicted based on LULC map of 1985, 2002, and 2017. LULC maps of the historical periods were delineated from Landsat images, and future LULC was predicted using the CA-Markov chain model. Precipitation for the future period was projected from six regional circulation models. The RUSLE model was used to estimate the current and future soil erosion rate in Muga watershed.

Results: The average annual rate of soil erosion in the study area was increased from about $15 \mathrm{t} \mathrm{ha}^{-1}$ year $^{-1}$ in 1985 to $19 \mathrm{t} \mathrm{ha}^{-1}$ year $^{-1}$ in 2002, and $19.7 \mathrm{t} \mathrm{ha}^{-1}$ year $^{-1}$ in 2017. Expansion of crop cultivation and loss of vegetation caused an increase in soil erosion. Unless proper measure is taken against the LULC changes, the rate of soil loss is expected to increase and reach about $20.7 \mathrm{t} \mathrm{ha}^{-1}$ year $^{-1}$ in 2033. In the 2050s, soil loss is projected to increase by $9.6 \%$ and $11.3 \%$ under RCP4.5 and RCP8.5, respectively, compared with the baseline period. Thus, the soil loss rate is expected to increase under both scenarios due to the higher erosive power of the future intense rainfall. When both LULC and climate changes act together, the mean annual soil loss rate shows a rise of $13.2 \%$ and $15.7 \%$ in the future under RCP4.5 and RCP8.5, respectively, which is due to synergistic effects.

Conclusions: The results of this study can be useful for formulating proper land use planning and investments to mitigate the adverse effect of LULC on soil loss. Furthermore, climate change will exacerbate the existing soil erosion problem and would need for vigorous proper conservation policies and investments to mitigate the negative impacts of climate change on soil loss.
\end{abstract}

Keywords: Cellular automata-Markov, Climate change, Impact, Land use/land cover, Soil erosion

\section{Introduction}

Soil is an indispensable resource; however, it has been affected by human beings since the beginning of agriculture (Amundson et al. 2015). Land use/land cover (LULC) and climate are expected to change in the future as a result of human activities (Field and Barros 2014) and expected to influence soil (Mengistu et al. 2015; de

\footnotetext{
*Correspondence: tatebelay@gmail.com

${ }^{1}$ Department of Geography and Environmental Studies, Debre Tabor University, Debra Tabor, Ethiopia

Full list of author information is available at the end of the article
}

Hipt et al. 2019; Anache et al. 2018; Berberoglu et al. 2020; $\mathrm{Hu}$ and Gao 2020). Soil erosion has become a significant threat to terrestrial ecosystems, and it denotes a vital environmental risk (Sun et al. 2013).

Blue Nile basin is one of the most diversified and noteworthy river basins in Ethiopia (Bewket and Teferi 2009; Melesse et al. 2009; Demessie 2015; Yalew et al. 2016; Gelete et al. 2019). Currently, the river basin faces severe environmental challenges, such as soil erosion, land degradation, loss of soil fertility, and deforestation (Steenhuis et al. 2013; Demessie 2015; Mengistu et al. 2015; 
Haregeweyn et al. 2017; Tadesse et al. 2017; Wubie et al. 2016; Yesuph and Dagnaw 2019).

In Ethiopia, soil erosion has been recognized as a serious environmental problem (Tamene and Vlek 2008; Haregeweyn et al. 2015, 2017). The loss of top fertile soil by water erosion creates severe limitations to sustainable agricultural land use, which leads to reduced soil productivity and food insecurity (Hurni et al. 2015).

Soil erosion jeopardizes the sustainability of agriculture and leads to siltation of streams, lakes, dams, and reservoirs (Haregeweyn et al. 2017; Yaekob et al. 2020) and downstream ecosystems impacts (Fenta et al. 2016). As a result, it can have serious implications for irrigation agriculture and related investments in different parts of the country. Thus, soil erosion caused by water is a severe problem of the country both in its onsite (e.g., productivity loss, soil fertility loss) and off-site effects (e.g., siltation) (Demessie 2015; Wagena et al. 2016; Berihun et al. 2019; Chimdessa et al. 2019; Yaekob et al. 2020; Aneseyee et al. 2020; Belihu et al. 2020). The risk varies across different areas, depending on the watershed landscape, local climatic conditions, soil characteristics, land use, and soil and water conservation and management practices. Therefore, it is a potential threat to the national food supply.

Numerous studies in Ethiopia (e.g., Mengistu et al. 2015; Taye et al. 2018; Tadesse et al. 2017; Haregeweyn et al. 2017; Gelagay and Minale 2016; Molla and Sisheber 2017; Hassen and Assen 2018; Miheretu and Yimer 2018; Anache et al. 2018; Ebabu et al. 2019; Berihun et al. 2019; Kidane et al. 2019; Aneseyee et al. 2020) reported that changes in climate and LULC could significantly affect the intensity of soil erosion at various spatiotemporal scales. For instance, Mengistu et al. (2015), reported the influence of temperature and precipitation on biomass production and soil organic carbon, thereby increasing soil erosion in the Abay river basin. An increase in precipitation levels and intensity will lead to intensified erosion (Field and Barros 2014).

Similarly, studies on the soil erosion caused by climate and LULC change were conducted in the Upper Blue Nile river basin of Ethiopia (e.g., Steenhuis et al. 2013; Demessie 2015; Mengistu et al. 2015; Wubie et al. 2016; Haregeweyn et al. 2017; Moges and Bhat 2017; Tadesse et al. 2017; Aneseyee et al. 2020). For instance, a study by Moges and Bhat (2017) in Rib watershed, and Tadesse et al. (2017) in Yezat watershed of the Upper Blue Nile basin, Ethiopia, showed that change in LULC of an area led to soil erosion. Mengistu et al. (2015) in the Abay river basin reported that climate change leads to soil erosion. These indicate that LULC change and changing precipitation patterns have an impact on soil erosion. Thus, to better understand the effects of LULC and climate change on soil erosion at a watershed level, a holistic and multidisciplinary approach is required. Modeling future soil loss rates due to climate and LULC change is an essential step (Mullan et al. 2012).

The effects of change in LULC and climate on soil erosion can be investigated by associating field measurements of soil erosion variables with different LULC classes and climate data (Adugna and Abegaz 2016; Ebabu et al. 2019). However, measurement of soil erosion is often not possible over the required temporal and spatial scale. Thus, field studies have to be complemented by soil erosion model simulation (Giri et al. 2015; Woznicki et al. 2016). Furthermore, results from soil erosion models have been used to predict impacts of climate and LULC change on soil erosion and as a scientific basis for soil erosion control and management at different scales (Addis and Klik 2015; Serpa et al. 2015; Woldesenbet et al. 2018; Anache et al. 2018).

Some researchers have developed and used different LULC change models depending on their study objectives and backgrounds. For instance, Araya and Cabral (2010) in Setúbal and Sesimbra, Portugal; de Oliveira Barros et al. (2018) in Montes Claros, Brazil; Omrani et al. (2017) in Luxembourg; Arsanjani et al. (2013) in Tehran; Xie et al. (2007) in China. Currently, the most widely used models in LULC change monitoring and prediction in Ethiopia are cellular and Markov chain models in Ethiopia (e.g., Gidey et al. 2017; Gashaw et al. 2018; Hishe et al. 2020; Kura and Beyene 2020; Fitawok et al. 2020; Mohamed and Worku 2020), and these models are verified in the Ethiopian context. Accordingly, the incorporation of GIS, CA-Markov model, climate model, and soil erosion models have been used to assess the effects of change in LULC and climate on soil erosion.

Studies including Maeda et al. (2010) in Kenya; Plangoen et al. (2013) in Thailand; Routschek et al. (2014) in Saxony, German; Ferreira et al. (2015) in the south of Portugal; Mengistu et al. (2015) in the Upper Blue Nile basin of Ethiopia; and Perović et al. (2019) in Vranjska Valley of Serbia were conducted to evaluate the potential impacts of climate change on soil erosion using soil erosion models with different scenarios. On the other hand, Sharma et al. (2011) in India; Plangoen et al. (2013) in Thailand; Ferreira et al. (2015) in the south of Portugal; de Hipt et al. (2019) in Burkina Faso, applied soil erosion model to simulate the potential effects of LULC change on soil erosion. The combined and separate effect of the current LULC and climate change on soil erosion were evaluated by several studies (e.g., Ferreira et al. 2015; Mengistu et al. 2015; de Hipt et al. 2019; Perović et al. 2019). Most of the studies focused on the separate effects of climate and LULC changes on soil erosion in different parts of the world. Although some researches were 


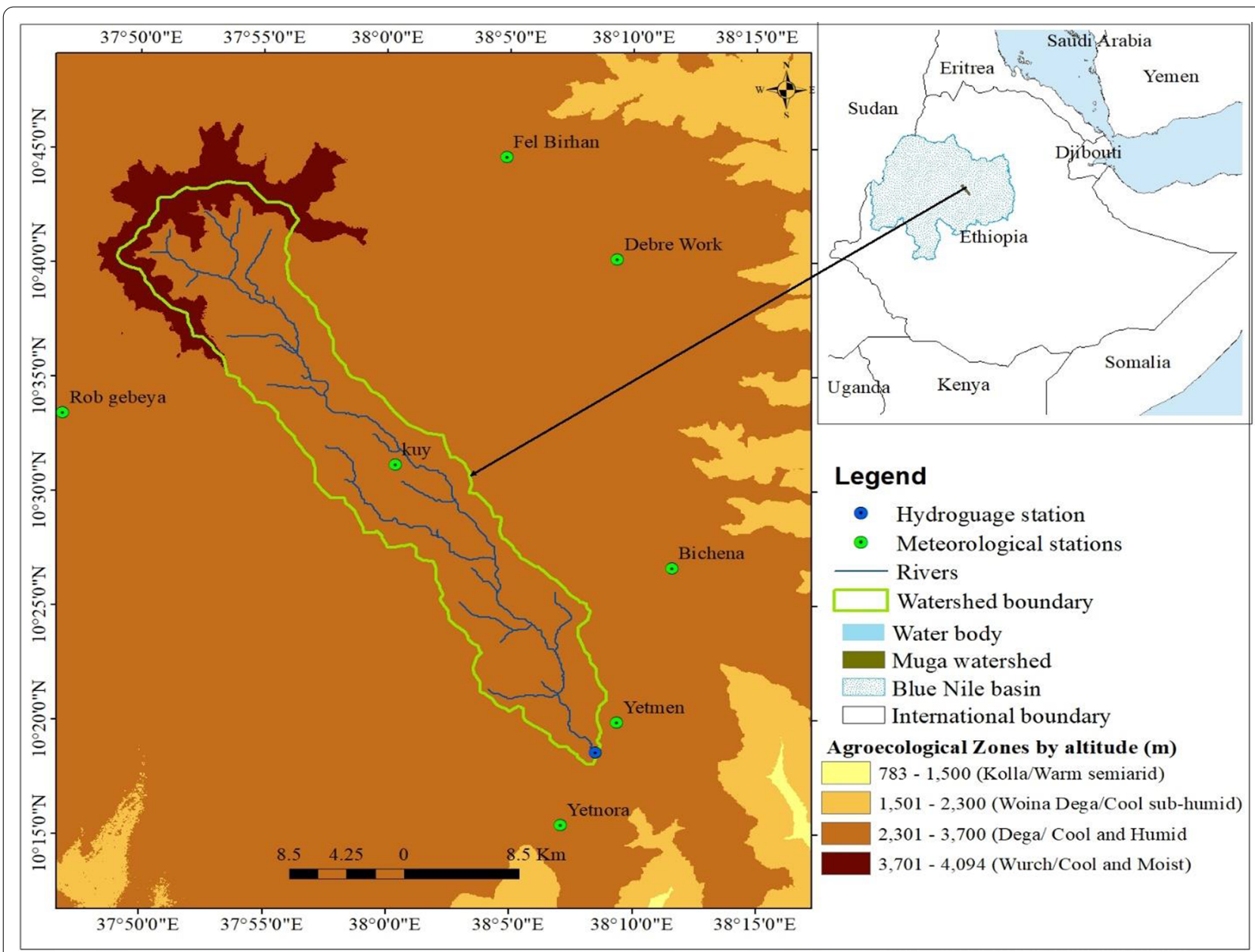

Fig. 1 Map of the study area

conducted on the combined and individual impacts of climate and land-use changes on soil erosion, the context is not yet well understood in the Upper Blue Nile basin. In addition, the environmental impact of future climate and LULC are still contentious issues and unresolved problems and require further research (Simane et al. 2013; Demessie 2015). Hence, predicting the impact of future climate and LULC changes on soil erosion is very important to design appropriate land use planning and adaptation and mitigation measures under local and regional scales.

The purpose of this study was to analyze the impact of LULC and climate change on soil erosion in the Muga watershed. This study would help to plan and use appropriate land use planning, soil and water conservation practices, decision making and policy development, thereby reduce soil erosion in the study area and watersheds with similar settings. Moreover, applying the CAMarkov chain model, climate model, and RUSLE model at the watershed level is the main contribution of this study in Ethiopia.

\section{Materials and methods}

\section{Study area}

This study was carried out at Muga watershed, located within $10^{\circ} 05^{\prime} 00^{\prime \prime} \mathrm{N}$ to $10^{\circ} 43^{\prime} 48^{\prime \prime} \mathrm{N}$ and $37^{\circ} 49^{\prime} 12^{\prime \prime} \mathrm{E}$ to $38^{\circ} 8^{\prime} 56^{\prime \prime} \mathrm{E}$, in the Upper Blue Nile basin, Ethiopia (Fig. 1). The area coverage is about $423 \mathrm{~km}^{2}$ from the top of mount Choke to the watershed's gauging station. The watershed's altitude varies from slightly over $2384 \mathrm{~m}$ above mean sea level (a.s.l) in the southern part to $4088 \mathrm{~m}$ a.s.l. The study site has two distinctive seasons: a wet season from May to October and a dry season that extends from November to April.

Based on the records from 32 years (1985-2017) at nearby meteorological stations, the annual rainfall depth ranges from 1020.7 to $1165.52 \mathrm{~mm}$. More than $85 \%$ of the rains fall during the wet season. The rainfall variability has significant impacts on agricultural production, 
hydrological processes, and soil erosion (Simane et al. 2013). The mean monthly minimum and the maximum temperature are about $9.3{ }^{\circ} \mathrm{C}$ and $23.7{ }^{\circ} \mathrm{C}$, respectively (Belay and Mengistu 2019).

The recent LULC map of the study area published in Belay and Mengistu (2019) shows that $74 \%$ of the watershed is covered by cultivated land, followed by grassland (11\%) and shrub-bushland (9.8\%), while forest land (2.3\%) and urban areas $(2.3 \%)$ covered a very small proportion of the study area. The cultivated land and urban areas showed an increasing trend between 1985 and 2017 (Belay and Mengistu 2019). Forest and shrub-bushlands are the most dominant in the upper escarpment of the watershed, while most of the cultivable lands and very small urban areas are found in the lower escarpment of the watershed.

According to the data obtained from the GIS department of the Ethiopian Ministry of Water and Energy, the geology of the study area consists of tertiary extrusive and intrusive deposits. The soil of the watershed is dominated by eutric vertisols (50.2\%) and eutric cambisols (26.5\%), followed by Haplic Luvisols (17.3\%) and Haplic Nitisols (6\%) (BCEOM 1998). Eutric Vertisols predominantly occurs in the lower parts of the study watershed.

\section{Data sources and processing}

The modeling of changing soil erosion requires past, present, and future climate and land use data as model input. Thus, LULC and climate change scenarios were simulated. The RUSLE model was used for this study to obtain the scenarios of soil erosion. The main components of the data set involved in the study were described in detail below.

\section{Image processing and preparation of spatial drivers}

To assess the impacts of LULC changes on soil erosion, LULC maps were prepared. Landsat Thematic Mapper (TM) of 1985, Landsat Enhanced Thematic Mapper Plus $\left(\mathrm{ETM}^{+}\right)$of 2002 , and Landsat Operational Landsat Imageries (OLI) of 2017 with path 169 and row 053 images were among the spatial data sets used and processed to generate LULC maps. For this study, the acquisition years were selected based on a 15-year interval to easily visualize changes in spatiotemporal LULC patterns.

Furthermore, Landsat images were selected for years that align with anticipated significant LULC changes in the study area. Accordingly, the 1985 image is indicative of conditions after the collectivization of land resources with the promotion of Agricultural Producer Cooperatives in Ethiopia including the study watershed during the Dergue regime (Crewett et al. 2008). The year 2002 represents the period aftermath of the Dergue regime, and the year was selected to evaluate the redistribution of
Table 1 List of time series Landsat data used for the study

\begin{tabular}{lllll}
\hline $\begin{array}{l}\text { Satellite and } \\
\text { sensor }\end{array}$ & Path/Row & $\begin{array}{l}\text { Acquisition } \\
\text { date }\end{array}$ & Resolution & Sources \\
\hline Landsat 5 TM & $169 / 53$ & 15 April 1985 & $30 \times 30$ & USGS \\
Landsat 7 ETM+ & $169 / 53$ & 08 March 2002 & $30 \times 30$ & USGS \\
Landsat 8 (OLI) & $169 / 53$ & 02 January 2017 & $30 \times 30$ & USGS \\
\hline
\end{tabular}

land to farmers. Finally, to include recent changes and the study area's current biophysical status, the 2017 Landsat image was used. However, due to Landsat images' accessibility and quality from USGS archives for the study watershed, a certain discrepancy in the time interval (+ 2 year) was taken into account. The images were downloaded from the USGS website (http://earthexplo rer.usgs.gov/) (Table 1).

The satellite imageries used in the study area were cloud-free and taken at the same season. The satellite images have gone through several pre-processing stages, such as layer stacking, mosaic, geometric correction, radiometric enhancement, and sub-setting using the Earth Resource Data Analysis System (ERDAS) imagine ${ }^{\circledR} 2015$ and $\operatorname{ArcGIS}{ }^{\circledR} 10.4$ software. All the satellite data sets were projected to the Universal Transverse Mercator map projection system zone $37 \mathrm{~N}$ and datum of World Geodetic System 84 (WGS84), which ensure consistency between data sets during analysis.

In this study, unsupervised and supervised image classification techniques were used to classify the Landsat images used in the study. The unsupervised classification was initially applied prior to the field survey using the visual interpretation method to differentiate various land use/cover types in the studied watershed. Unsupervised classifications were carried out using Iterative Self-Organizing Data Analysis (ISODATA) clustering algorithm. The LULC maps of the study area were produced using the pixel-based supervised image classification with the maximum likelihood classification algorithm (Congalton and Green 2019). Supervised image classification is a recommended classification approach to achieve good results when adequate training data are available for the study area (Lillesand et al. 2015; Congalton and Green 2019). First, about five LULC classes (grassland, cultivated land, shrub-bush land, forest, and urban area) were identified from the images. Then, about 300 samples (60 samples per LULC class) were randomly selected from five LULC types as training points, whereas 300 samples were used for accuracy assessment based on Lillesand et al. (2015) and Congalton and Green (2019). Besides, high-resolution data (SPOT images and Google Earth), topographic maps, and data from field observations and knowledge of the elderly were used. 
The accuracy assessments of all the classified images were conducted using ground control points collected from: (1) a topographic map, (2) Woody Biomass Inventory and Strategic Planning Project data, (3) knowledge of elderly people, field data, and (4) Google Earth data sets on ERDAS IMAGINE environment. Ground control points were collected from each LULC type and used as a reference for the accuracy assessment. The classification's overall accuracy for the years 1985, 2002, and 2017 is $85.7 \%, 87.9 \%$, and $89 \%$, respectively, with kappa values of $0.82,0.86$, and 0.86 . The accuracy statistics and kappa coefficient values are well above the recommended values (Congalton and Green 2019).

In this study, the CA-Markov chain model was used to simulate and predict the future land cover map of 2033. Different sets of spatial and non-spatial data were used as input to the CA-Markov model. The simulation and prediction processes were performed using LULC maps of 1985,2002 , and 2017, roads and towns, distance to a river, slope, and elevation maps. The LULC maps of 1985 , 2002, and 2017 were mainly used to generate transitional matrix using the Markov chain process. Besides maps of a slope, road, settlement, and elevations maps were used to create transitional potential maps. The data sets were used in combination to predict future change in the LULC using the CA-Markov chain model. Potential land-use change drivers were identified through literature reviews (Bewket and Teferi 2009; Teferi et al. 2013; Gidey et al. 2017; Hishe et al. 2020) and field interviews with farmers, local farming experts, regional land bureau officials, and through spatial correlations.

A digital elevation model (DEM) of $30 \mathrm{~m}$ resolution from the Advanced Spaceborne Thermal Emission and Reflection Radiometer (ASTER) was used to prepare the watershed's slope, elevation, and stream network of the study watershed. The watershed road network was also downloaded from OpenStreetMap (https://www.opens treetmap.org/), and its geometric consistency was verified in QGIS software. The population data set for the study area was obtained from the Ethiopian Central Statistical Agency (CSA). Consequently, these data sets were produced using ArcGIS software and then exported to IDRISI Selva to run the potential transition maps. The list and sources of data sets used to analyze future land use map and RUSLE model in the Muga watershed is presented in Table 2.

\section{Climate data}

Two climate data sets: baseline and modeled climate data, were used in this study. The baseline climate data were used to estimate the baseline soil loss and validate the predicted climate scenarios. The rainfall data were compiled from seven meteorological stations operating
Table 2 Data set sources and types

\begin{tabular}{lll}
\hline No & Name of data & Sources \\
\hline 1 & Digital Elevation Model (DEM) $(30 \mathrm{~m})$ & USGS \\
2 & Soil data of the watershed & MoWIE \\
3 & Daily precipitation data from 1985 to 2017 & $\begin{array}{l}\text { National mete- } \\
\text { orological agency of } \\
\end{array}$ \\
& Ethiopia \\
4 & Road & OpenStreetMap \\
\hline
\end{tabular}

within and around the study watershed from 1985 to 2017; we obtained the data from the National Metrological Agency (EMA) of Ethiopia.

Climate models were used to quantify the relative change in the current and future climate, often used as an input to the soil erosion models. The present study used six regional climate models (RCMs) with the driving model ICHEC-EC-EARTH under CORDEX (Coordinated Regional Climate Downscaling Experiment)-Africa (Fick and Hijmans 2017; Shamir et al. 2015). CORDEX-Africa provides projected climate outputs at a relatively higher spatial resolution $(50 \mathrm{~km})$. The models were: HadGEM2-ES, CSIRO-Mk3.6.0, GFDL-ESM2M, CanESM2, MIROC, and NorESM1-M, because these models are appropriate based on earlier research conducted in other parts of Ethiopia (Alemseged and Tom 2015; Teklesadik et al. 2017; Worku et al. 2018).

The representative concentration pathways (RCPs) scenarios RCP4.5 and RCP8.5 were considered for this study to drive the RUSLE model (Alemseged and Tom 2015). Policymakers usually focus on events occurring in the 2050s compared to the events in the far future (Weber 2006). Thus, the authors select climate change data from 2018 to 2050 rather than the end of the century.

The CORDEX grid points were extracted using MATLAB software. It is recognized that climate model output data contain systematic errors and cannot be used immediately in soil and hydrological simulations (Christensen et al. 2008; Teutschbein and Seibert 2010, 2012; Chen et al. 2016). Thus, the RCM climate data outputs in CORDEX-Africa under emission scenarios RCP4.5 and RCP8.5 were bias-corrected for this study.

\section{Methods \\ Land use land cover prediction using CA-Markov chain model}

Several LULC change models were developed (e.g., Veldkamp and Lambin 2001; Parker et al. 2003; Verburg et al. 2004; Koomen and Stillwell 2007). Some of the most widely used LULC models include statistical models (regression) (Yalew et al. 2016), Cellular automata (CA), and Markov chains (Araya and Cabral 2010; Han et al. 2015; de Oliveira Barros et al. 2018; Munthali et al. 2020), 
evolutionary models (neural networks) (Omrani et al. 2017), and multi-agent-based models (Xie et al. 2007; Arsanjani et al. 2013). These approaches are often combined to create an integrated model that determines the probabilities of LULC changes. Frequently, the choice of models depends on the study's objective and the level of complexity required (Nainggolan et al. 2012).

The Markov Chain model of LULC change has been widely used to predict LU changes (Sang et al. 2011) and usually integrated with a cellular automata (CA) model with an agent-based model to express the human interaction on the landscape (Xie et al. 2007; Ralha et al. 2013). This is due to its reliability and compatibility with many geospatial technologies (Halmy et al. 2015). The reliability and compatibilities of the CA and Markov chain model was checked in the Ethiopian context by Gidey et al. (2017), Gashaw et al. (2018) and Hishe et al. (2020). Thus, this study used the CA-Markov chain model integrated with the multi-criteria evaluation to predict LULC of 2033 in the Muga watershed. The Markov chain model provides the probability and extent of LULC change, whereas the CA model operates on neighborhood interactions and spatial distribution.

The complex interrelationships between the physical and human factors lead to the conversion from one land use type to another (Eastman 2012). Thus, with the CA-Markov model, a multi-criteria evaluation (MCE) technique was used to support land allocation decision process using different land use criteria (Al-Sharif and Pradhan 2014; Deng et al. 2015). The MCE is useful for studying the land use suitability for the possible conversion of certain land use to another, revealing each criterion's influence and importance (Yalew et al. 2016; Gidey et al. 2017).

\section{Preparation of suitability maps}

LULC can be driven by a multitude of socio-economic and biophysical factors. The future change in LULC can be determined by the inherent change and external factors/spatial variables, such as the proximity to towns, distance from a river and city, elevation, slope, and areas suitable for each change in each class. A slope was considered as a constraint for cultivation and urban areas because steep slopes prohibit both cultivation and urban expansion.

An integrated evaluation procedure was used to generate potential transition maps based on biophysical and socioeconomic indicators. In this regard, more than five biophysical and socio-economic variables including elevation, slope, distance to towns, and distance to roads were considered (Additional file 1: Fig. S2). The selected transition potential maps are in different units. Therefore, the maps were converted into a uniform measurement scale through standardization techniques for weighted overlay analysis (WOA) (Reshmidevi et al. 2009; Zabihi et al. 2015). Once all the maps were standardized, the weight for each criterion was calculated using the analytical hierarchy process (AHP) (Yalew et al. 2016; Gidey et al. 2017).

Consequently, specific weights were assigned to each factor (Hishe et al. 2020) and used to compute suitable maps in IDRISI software. The relative weights for a group of factors were defined based on the authors' knowledge and experience about the studied landscape, a review of the scientific literature, and the farmers' and local experts' opinions. The highest weight value is the most influential factor, while the lowest is a less important LULC change factor. After determining each criterion layer's relative importance through a pairwise comparison matrix, these values were entered using IDRISI software to produce associated weights and consistency ratio value.

Table 3 shows inputs to the pairwise comparison for the AHP analysis to determine weights. The weights produced from the AHP procedure using the inputs in Table 3 are between 0 and 1 , where 0 denotes the no probability and 1 the high probability. The consistency ratio of the pairwise comparisons for the computation of criteria weights is shown in Table 3, which is an acceptable range (Eastman 2012). Consequently, a weighted overlay analysis was performed using IDRISI software.

As shown in Table 4, the 1985-2002 transition matrix and the 2002 transition potential maps were integrated to simulate LULC map of 2017. The data were integrated using the CA model to simulate LULC of 2017. The same procedure was used to predict the LULC of 2033. The transition matrix from 2002 to 2017 and transition potential map of 2017 were integrated to run the prediction for 2033.

\section{Validation of LULC prediction model}

Model calibration and validation are essential in predicting future decadal changes, where no data sets are available for predicted data accuracy (Srivastava et al. 2014; Singh et al. 2015). To validate the model, the actual LULC map of the year 2017 was compared with the 2017 map simulated by CA-Markov and based on the kappa statistics and a comparison of each simulated LULC class with the real class has been used. According to the CAMarkov model's required preparation, a calibration map for 2017 was prepared. The number of repetitions in the model was set equal to the number of years between the reference map and the map predicted by the model (15 years). The actual 2017 LULC map was then used as a reference map to compare with the 2017 simulated LULC map results. Accordingly, the analysis result has shown 
Table 3 Factors and constraints considered and their weights for predicting LULC conditions in Muga watershed

\begin{tabular}{|c|c|c|c|c|}
\hline Land use types & Factors & Factor weight & Consistency & $\begin{array}{l}\text { Constraint } \\
\text { and classes } \\
\text { considered }\end{array}$ \\
\hline \multirow[t]{4}{*}{ Cultivated land } & Suitable areas for conversion to cultivation & 0.420 & 0.04 & Slope $\left(>15\right.$ to $\left.58^{\circ}\right)$ \\
\hline & Proximity to developed land & 0.269 & & \\
\hline & Distance to rivers & 0.109 & & \\
\hline & Elevation & 0.201 & & \\
\hline \multirow[t]{3}{*}{ Shrub-bushland } & Suitable areas for conversion to shrub-bushland & 0.328 & 0.01 & Slope (None) \\
\hline & Proximate to developed land & 0.396 & & \\
\hline & Elevation & 0.206 & & \\
\hline \multirow[t]{3}{*}{ Grassland } & Suitable areas for conversion to grassland & 0.110 & 0.03 & Slope (None) \\
\hline & Proximate to developed land & 0.582 & & \\
\hline & Elevation & 0.309 & & \\
\hline \multirow[t]{3}{*}{ Forest } & Suitable areas for conversion to forest & 0.425 & 0.04 & Slope (None) \\
\hline & Proximate to developed land & 0.213 & & \\
\hline & Elevation & 0.080 & & \\
\hline \multirow[t]{5}{*}{ Urban area } & Suitable areas for conversion to urban & 0.160 & 0.01 & Slope $\left(>13\right.$ to $\left.58^{\circ}\right)$ \\
\hline & Proximate to developed land & 0.166 & & \\
\hline & Distance to urban & 0.417 & & \\
\hline & Distance to roads & 0.160 & & \\
\hline & Elevation & 0.090 & & \\
\hline
\end{tabular}

Table 4 Markov chain transition probability matrix of land use land cover types for the period 2002-2017

\begin{tabular}{|c|c|c|c|c|c|}
\hline \multirow[t]{2}{*}{ LULC } & \multicolumn{5}{|c|}{ Probability of changing to 2017} \\
\hline & Built-up & Shrub-bushland & Forest & Cultivated land & Grassland \\
\hline \multicolumn{6}{|c|}{ Probability of changing from 2002} \\
\hline Bulit-up & 0.09 & 0.00 & 0.00 & 0.78 & 0.13 \\
\hline Shrub-bushland & 0.00 & 0.57 & 0.08 & 0.33 & 0.02 \\
\hline Forest & 0.00 & 0.43 & 0.54 & 0.03 & 0.00 \\
\hline Cultivated & 0.02 & 0.01 & 0.00 & 0.83 & 0.13 \\
\hline Grassland & 0.00 & 0.28 & 0.00 & 0.41 & 0.30 \\
\hline
\end{tabular}

The bold number indicates the total area of each LULC class that remained unchanged

consistency between the reference and the simulated LULC maps of 2017.

Furthermore, an attempt was also made to examine its accuracy using the kappa coefficient. The Kappa variations used to validate the CA-Markov model for LULC change predictions in this study were computing the kappa coefficient using a validated tool in IDRIS Selva software. Kappa statistics are used for testing accuracy are the traditional Kappa $\left(\mathrm{K}_{\text {standard }}\right)$ or Kappa for no information/ability $\left(\mathrm{K}_{\mathrm{no}}\right)$, Kappa for location $\left(\mathrm{K}_{\text {location }}\right)$, and quantity of correct cells (Kappa for quantity). Kappa variations have been strongly recommended and widely used to validate LULC change predictions (Pontius Jr 2002; Singh et al. 2015).
The Kappa coefficient for quality and location was computed. The statistics show that $\mathrm{K}_{\mathrm{no}}$ is $0.8803, \mathrm{~K}_{\text {location }}$ is 0.8270 , and $\mathrm{K}_{\text {standard }}$ is 0.8141 (overall). The $K$ values are greater than 0.8 , showing the model accuracy to predict future LULC change. In other words, the kappa coefficient result indicates the model's ability to specify grid cell level location of future change is nearly perfect (Mondal et al. 2016). The result indicates that $K$ values of 0.80 and above are considered strong and reasonable to make plausible future projections (Yang et al. 2014; Gidey et al. 2017). The LULC scenario was prepared for 2033, accounting for the implications of future land use on soil erosion due to the variation in $C$ factor. Figure 2 shows 


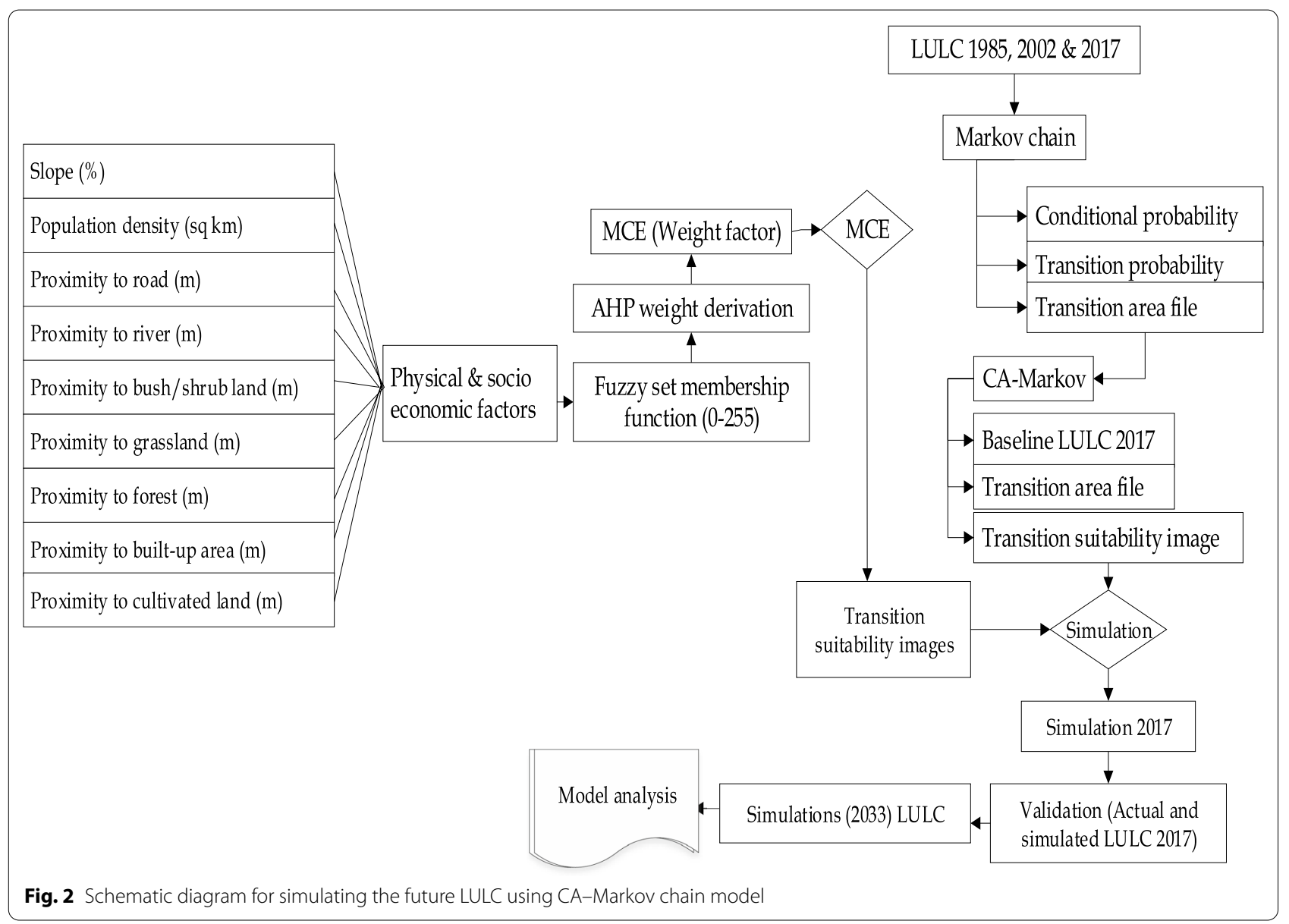

the process for simulating the future LULC using CAMarkov chain model.

\section{Climate projection and bias correction}

Climate projection Climate scenarios have served as an essential tool in climate change research in the past and will likely continue to do so in the future. There are four greenhouse gas scenarios recently published in the fifth IPCC Assessment Report (AR5), called the representative concentration pathways named based on their possible range of radiative forcing values, such as (RCPs) 2.5, 4.5, 6 , and 8.5. In the present study, we selected two climate change scenario data (Representative Concentration Pathways: RCP4.5 and RCP8.5) that cover the entire range of radiative forcing from the newly available Coupled Model Intercomparison Project Phase 5 (CMIP5). The output of the RCM ensemble of the Coordinated Regional Climate Downscaling Experiment (CORDEX) for African domain projection was used as an input to the hydrological model.

RCP4.5 scenario is medium-term emission scenario at the stabilization level of about $4.5 \mathrm{w} / \mathrm{m}^{2}$ (about $650 \mathrm{ppm}$ $\mathrm{CO}_{2}$ equivalent) not exceeding this value by the year 2100
(Meinshausen et al. 2011; van Vuuren et al. 2011), supposing that all countries around the world undertake emission mitigation policies (Thomson et al. 2011). RCP8.5 scenario is the worst-case scenario in terms of greenhouse gas emissions, with no clear climate policy. The RCP8.5 scenario shows a radiative forcing pathway leading to $8.5 \mathrm{w} / \mathrm{m}^{2}$ (greater than $1370 \mathrm{ppm} \mathrm{CO}_{2}$-equivalent) in 2100 (van Vuuren et al. 2011). Climate scenario data sets consist of a historical run (1976-2005) and projection (2018-2050) with a spatial resolution of $0.44^{\circ}$ based on the emission scenarios of RCP4.5 and RCP8.5. In this study, climate data up to 2050 (2018-2050) was used rather than considering the end of the century, as small and large dams (with a lifespan of 30 to 50 years) in the upper Blue Nile basin of Ethiopia, including the study watershed, has been studied, designed, and started to implement for irrigation and hydropower purposes, which will be affected by a changing climate in the short period of time; and policymakers often focus on what is happening sooner than what is happening in the distant future (Weber 2006). 
Table 5 Regional Climate Models (RCMs) in the CORDEX-Africa used in this study

\begin{tabular}{lll}
\hline Institution & RCM name & Country \\
\hline CSIRO-Commonwealth Scientific and Industrial Research Organization & CSIRO-Mk3.6.0 & Australia \\
NOAA GFDL: Geophysical Fluid Dynamics Laboratory & GFDL-ESM2M & USA \\
MOHC: Met Office Hadley Centre & HadGEM2-ES & United Kingdom \\
CCCma: Canadian Centre for Climate Modelling and Analysis & CanESM2 & Canada \\
NCC: The Norwegian Climate Centre & NorESM1-M & Norway \\
MIROC: Developed by the Japanese research community & MIROC & Japan \\
\hline
\end{tabular}

The CMIP5 data for two specific periods (historical and future periods) were downloaded from https://esgf-node. llnl.gov/projects/esgf-llnl/. The grid points of the regional climate scenarios (daily precipitation and maximum and minimum air temperature data) were extracted using MATLAB software. The software was also used to convert NetCDF files into text format, taking into account the spatial references of a particular weather station. Seven stations were used to extract the downloaded data: Bichena, Debre Work, Felege Birhan, Kuy, Rob Gebeya, Yetemn, and Yetnora. The models were: HadGEM2-ES, CSIRO-Mk3.6.0, GFDL-ESM2M, CanESM2, MIROC, and NorESM1-M, as these models are appropriate based on earlier research conducted in other parts of Ethiopia (Alemseged and Tom 2015; Teklesadik et al. 2017; Worku et al. 2018) (Table 5). In this study, the six models' ensemble mean was computed and used as input for the RUSLE model.

\section{Bias correction of regional climate models simulation}

The relatively low spatial resolution of GCMs and RCMs outputs systematic errors, such as estimation of climate variables (over or under), inaccurate estimates of seasonal variations of precipitation (Christensen et al. 2008), and more wet-less days compared to observed data (Ines and Hansen 2006). As a result, the data from RCPs were bias-corrected to prevent over-or-under estimation and to ensure a realistic representation of the future climate. Because climate model output cannot be used as direct input data for hydrological simulations (Christensen et al. 2008; Teutschbein and Seibert 2010, 2012; Chen et al. 2016), the model performance in simulating the observed precipitation and maximum and minimum temperature were assessed, and those with unacceptable time seriesbased metrics results were bias-corrected. The historical RCMs and observed data were used for bias correction. Therefore, RCM outputs (precipitation) are typically adjusted to eliminate any bias (Maraun 2012; Teutschbein and Seibert 2012).

Several bias correction techniques were developed to correct the bias, ranging from very simple to more complex methods, such as quantile mapping $(\mathrm{QM})$, general quantile mapping (GQM), power transformation (PT), and linear scaling (LS) (Teutschbein and Seibert 2012). They can be classified according to the degree of their complexity and simpler methods, such as scaling factors, and more sophisticated techniques, such as probability mapping. Although the RCM climate variables' bias correction significantly improves hydrological modeling, there is a major drawback. All bias correction methods are based on the assumption of static model errors (Teutschbein and Seibert 2012). This means that the correlation algorithm for current climate conditions and its parameters are considered valid even under the changing climate conditions.

According to Teutschbein and Seibert (2012) and Sisay et al. (2017), linear scaling is a simple technique and provides better efficiency in correcting the ensemble RCMs climatological biases. In this study, the linear scaling bias correction method was applied to adjust the raw ensemble of climate scenarios (rainfall) output simulation data.

The linear scaling bias correction method was selected following a review of the study by Teutschbein and Seibert (2010), which evaluated five bias correction methods for precipitation and showed that linear scaling is suitable for precipitation. The linear scaling method uses a correction factor for each month based on long-term historical RCM data and the observed data. Correction factors were applied for future climate scenarios of the RCP4.5 and RCP8.5 emissions. The bias correction was used to estimate and remove the bias correction in future RCMs output. The linear scaling bias correction method (V.1.0) Microsoft Excel file described by Shrestha (2015) was used in this study to adjust the climate model's average value to observations appropriately.

To verify the bias correction method and the improvement obtained after bias correction, the average daily observed and simulated data (before and after bias correction) were again compared with the observed data by model evaluation statistical methods, such as the correction coefficient $(r)$ and root mean square error (RMSE). Statistical results of the bias correction show that the bias correction significantly improves the simulated data as the RMSE values decrease, the SD values closer to 
observed data. The correlation coefficient between the observed and simulated data was significantly improved from 0.74 to 0.76 for rainfall data. It indicates that the bias-corrected values better represent the patterns of precipitation over the study watershed. This result showed that the bias correction result is acceptable and consistent with the results of previous studies (Gebre and Ludwig 2015; Sisay et al. 2017). The two RCP scenarios (RCP4.5 and RCP8.5) were taken into account to estimate the rainfall erosivity factor.

\section{Revised Universal Soil Loss Equation model}

In the present study, we used the RUSLE model for erosion modeling. RUSLE is the revised form of the USLE model (Wischmeier and Smith 1978), with substantial improvements in predicting the yearly amount of soil loss; and it was revised by Nyssen et al. (2009) to the Ethiopian conditions. The annual soil loss $(A)$ of the study watershed was calculated by overlaying five raster layers using the following equation:

$$
A=R * K * \mathrm{LS} * C * P
$$

where $A$ is the average annual soil loss per unit area $\left(\mathrm{t} \mathrm{ha}^{-1}\right.$ year $\left.^{-1}\right), \quad R$ is rainfall erosiv-
In the present study, the annual rainfall erosivity was calculated according to the method of Hurni (1985) to the Ethiopian highlands as the following equation:

$$
R=-8.12+0.562 P
$$

where $R$ is the rainfall erosivity factor (in MJ mm ha ${ }^{-1} \mathrm{~h}^{-1}$ year $^{-1}$ ), and $P$ is the mean annual rainfall (mm).

After accounting the $R$ factor of the baseline (19852017) and future period (2018-2050) using the mathematical equation, the $R$ factor raster was created using the Inverse Distance Weighted (IDW) interpolation method in the Geostatistical Analysis extension of ArcGIS 10.4 software.

Soil erodibility factor ( $K$-factor) represents soil vulnerability to erosion (Wischmeier and Smith 1978). According to the soil difference, the $K$ value of an area is also different depending on the parameters of soil texture, organic matter content, and permeability (Renard 1997). The soil erodibility was determined from the available soil data of the Blue Nile river basin (scale 1:250,000), which was obtained from the Ministry of Water and Energy. In this study, we used the nomograph method to calculated the $K$ value as proposed by Wischmeier et al. (1971)

$$
\begin{aligned}
& K_{\text {fact }}=(1.292)\left[2.1 * 10^{-6} f_{\mathrm{p}}^{1.14}\left(12-p_{\text {om }}\right)+0.0325\left(S_{\text {struc }}-2\right)+0.025\left(f_{\text {perm }}-3\right)\right] \\
& \text { in which } \\
& f_{\mathrm{p}}=p_{\text {silt }}\left(100-p_{\text {clay }}\right)
\end{aligned}
$$

ity (MJ $\mathrm{mm} \mathrm{ha}^{-1} \mathrm{~h}^{-1}$ year $^{-1}$ ), $K$ is soil erodibility $\left(\mathrm{t} \mathrm{ha}{ }^{-1} \mathrm{MJ}^{-1} \mathrm{~mm}^{-1}\right), L S$ is the slope length and steepness factor, $C$ is a cover and management factor, and $P$ is the conservation practice factor. The procedures and techniques we used for these factors are presented in the following sections.

Rainfall erosivity factor ( $R$-factor) indicates the input, which represents the effect of rainfall intensity on soil erosion and requires in-depth, unceasing precipitation data for its calculation (Renard and Freimund 1994; Angima et al. 2003). The rainfall erosivity is calculated as the total storm energy multiplied by the maximum 30 min intensity (Renard 1997). However, such data is not available for the study area, limiting the $R$ factor spatiotemporal application. Empirical relationships between measured rainfall amount and $R$-factor values widely used as an alternative approach (Hurni 1985; Nigussie et al. 2014; Mengistu et al. 2015). This method is widely used by previous researchers in Ethiopia and other countries (e.g., Bewket and Teferi 2009; Mengistu et al. 2015; Tamene and Le 2015; Duarte et al. 2016; Gelagay and Minale 2016; Haregeweyn et al. 2017; Molla and Sisheber 2017). where $f_{\mathrm{p}}$ is the particle size parameter (unitless), $p_{\text {om }}$ is the percent organic matter (unitless), $s_{\text {struc }}$ is the soil structure index (unitless), $f_{\text {perm }}$ is the profile-permeability class factor (unitless), $p_{\text {silt }}$ is the percent silt (unitless) and $p_{\text {clay }}$ is the percent clay (unitless).

In Eq. 3 the factor (1.292) is needed to convert $K$-factor from the imperial to the international system units (i.e., SI metric units) (Streile et al. 1996). The soil structure index, $S_{\text {struc }}$, is 4 for blocky, platy, or massive soil, 3 for medium or coarse granular soil, 2 for fine granular soil, and 1 for very fine granular soil (Mengistu et al. 2015). The profile-permeability class factor, $f_{\text {perm }}$, is 1 for very slow infiltration, 2 for slow infiltration, 3 for slow to moderate infiltration, 4 for moderate infiltration, 5 for moderate to rapid infiltration, and 6 for rapid infiltration (Streile et al. 1996). In general, Eq. 3 can help capture relative differences in erodibility between soil types and help appropriate the resistance to erosion of different soils under consideration (Ganasri and Ramesh 2016). The soil type and soil erodibility map of the watershed is presented in Fig. 3.

Topographic factor ( $L S$-factor) refers to the effect of topography on soil erosion. The slope length $(L)$ and slope gradient $(S)$ factors are joined in a single index, 


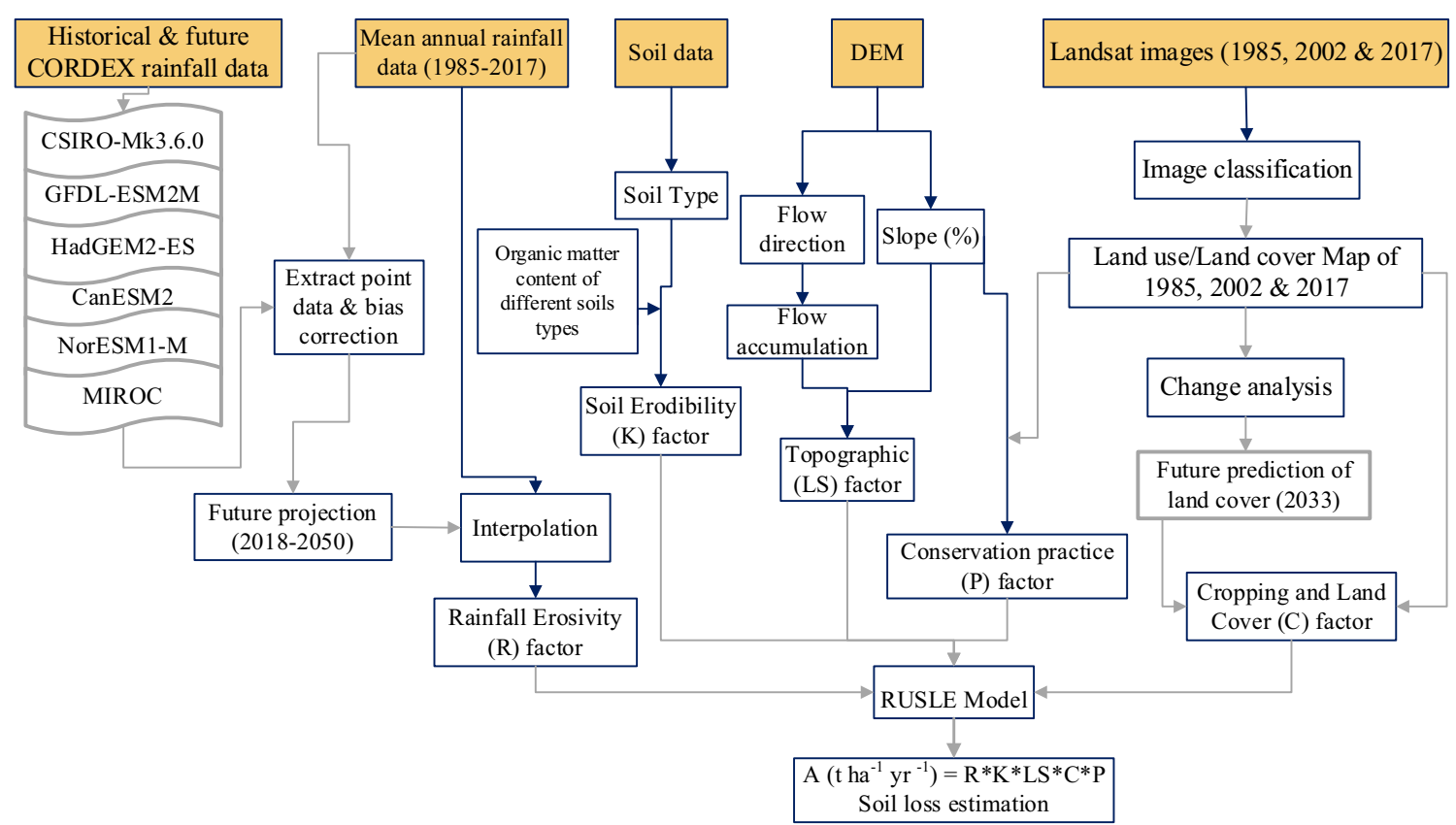

Fig. 3 Soil type (a) and soil erodibility factor map (b) of Muga watershed

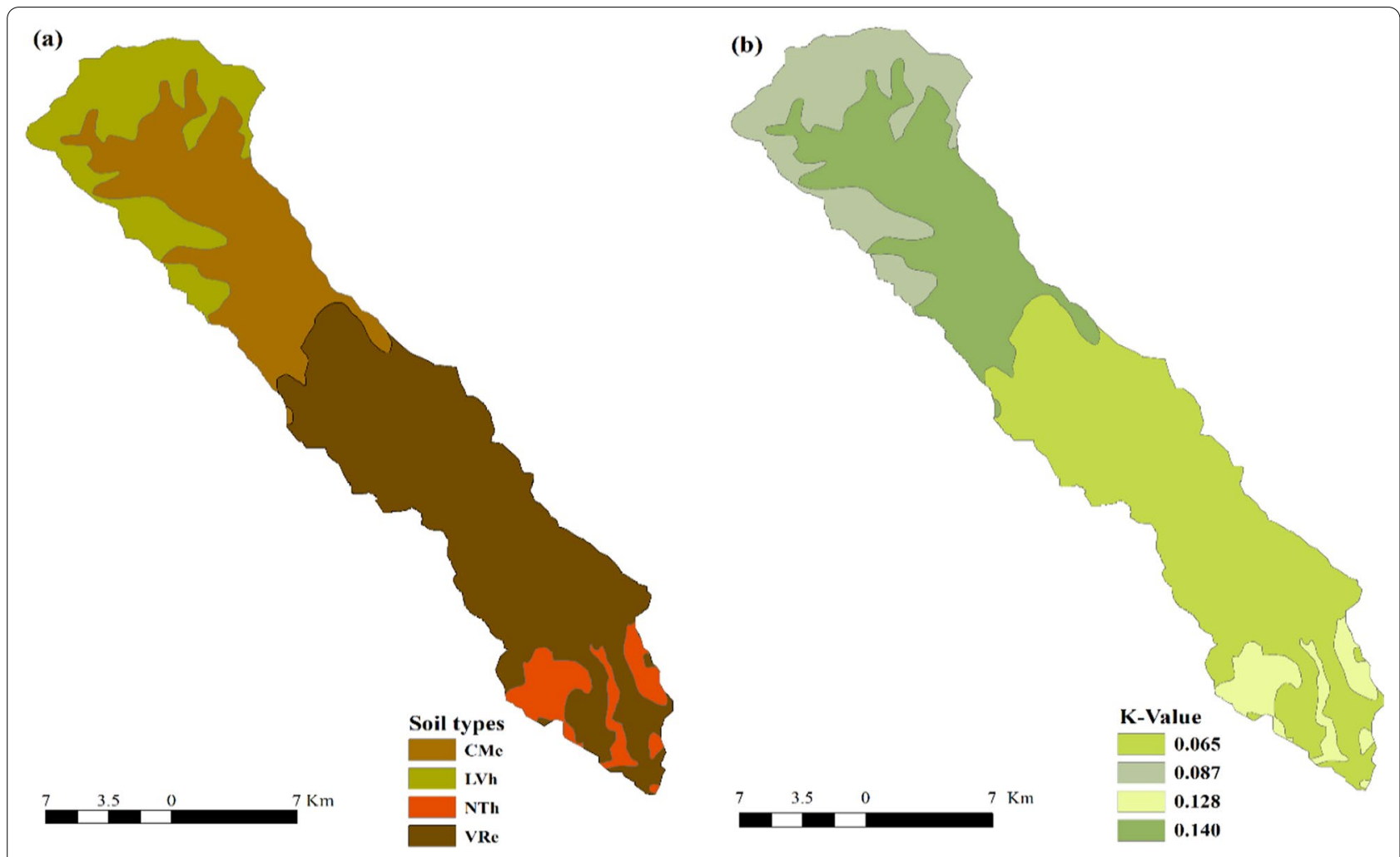

Fig. 4 Slope length and steepness factor (LS-factor) map of Muga watershed 
Table 6 C-factor and P-factor values for the respective land use/land cover classes of Muga watershed, Upper Blue Nile Basin, Ethiopia

\begin{tabular}{lll}
\hline Land use/land cover classes & C factor & P factor \\
\hline Grassland & 0.05 (Hurni 1985; Bewket and Teferi 2009) & 0.8 (Hurni 1985; Adugna et al. 2015) \\
Cultivated land & 0.15 (Hurni 1985; Adugna et al. 2015) & 0.9 (Bewket and Teferi 2009; \\
& & Adugna et al. 2015; Taye et al. 2018) \\
Shrub-bushland & 0.02 (Mengistu et al. 2015) & 0.8 (Hurni 1985) \\
Forest & 0.05 (Molla and Sisheber 2017) & 0.8 (Hurni 1985) \\
Urban area & 0.05 (Moges and Bhat 2017) & 0.8 (Hurni 1985) \\
\hline
\end{tabular}

$L S$-factor, to describe the topographic factor for soil loss. The slope length refers to the distance from the point of origin of overland flow to the point, where either the slope gradient declines enough in which sedimentation starts or the runoff water enters a well-defined channel (Renard 1997). The $L S$ factor represents (Fig. 4) the ratio of soil loss per unit area on-site to the corresponding loss from a $22.13 \mathrm{~m}$ long experimental plot with a 9\% slope (Renard 1997). Higher slope lengths may increase the overland flow and lead to more land surface soil erosion (Moore and Burch 1986a). Moreover, higher slope gradients also promote the runoff rate and bring out more soil erosion.

In this study, the $L$ factor was computed following Eq. (4) proposed by Moore and Burch (1986a; b). The algorithm (Eq. 5) recommended by Desmet and Govers (1996) was used to calculate the $S$ factor. It is based on flow accumulation and slope steepness. The slope steepness $(S)$ factor was calculated for high (>9\%) and low slope land $(<9 \%)$ from the slope angle. Finally, the $L$ and $S$ factor were multiplied to derive the $L S$ factor for the study watershed using the Spatial Analysis Tool Map Algebra Calculator in the ArcGIS 10.4 environment and the spatial variability of the slope length steepness factors (Renard 1997):

$$
\begin{gathered}
\left.L=\begin{array}{c}
\left(\frac{\lambda}{22.1}\right)^{m}, \\
\text { where }
\end{array}\right\} \\
\left.m=\frac{\beta}{(1+\beta)}, \beta=\frac{\left(\frac{\sin \theta}{0.0896}\right)}{3\left(\sin \theta^{0.8}+0.56\right)}\right\} \\
S=\left\{\begin{array}{l}
10.8 * \sin \theta+0.03, \text { where slope gradient }<9 \% \\
16.8 * \sin \theta-0.5, \text { where slope gradient } \geq 9 \%
\end{array}\right.
\end{gathered}
$$

where $L$ and $S$ indicate slope length and steepness factor (dimensionless); $\lambda$ is the slope length (in meter), cell size is the size of the grid cell (for this study $30 \mathrm{~m}$ ); $m$ is an adjustable slope length exponent to $\beta$; while $\beta$ represents the rill to interrill erosion ratio; and $\theta$ is the slope angle (in degrees).
The study area's topography is steep with non-uniform terrain on the upper parts of the watershed, whereas the area's lower escarpment is gentle and uniform. The combined steeper and longer slopes resulted in larger cumulative runoff volumes with high velocity and erosive power.

Cover management factor ( $C$-factor) represents the effect of vegetation and the cover on the amount of soil erosion (Bewket and Teferi 2009; Haregeweyn et al. 2017). The individual values of $C$ vary between 0 for a completely non-erodible condition, and 1 implies conditions more erodible than those normally experienced under unit plot conditions, which can occur for conditions with very extensive tillage, and $C$ is strongly related to land use.

In Ethiopia, satellite-derived images are a good proxy for land cover on relatively large basins and watershed levels and were applied in the Upper Blue Nile basin of Ethiopia (Bewket and Teferi 2009; Mengistu et al. 2015; Molla and Sisheber 2017; Taye et al. 2018). In this study, $C$ values were determined based on the most recent (2017) and predicted future (2033) land use data, as suggested in the literature (Table 6).

Conservation practice ( $P$-factor) reflects the effects of support practices, such as terracing and contour tillage, to reduce the rate of soil erosion (Renard 1997). The higher the $P$ factor, the less effectively the practice facilities deposition to take place close to the source. It is primarily used to assess the effects of conservation measures implemented on soil loss (Mengistu et al. 2015). Our field visits indicated that soil and water conservation activities are not widely practiced in the study area. However, farmers commonly use stone bunds and contour farming to protect the soil from erosion. Still, they are poorly maintained as implementation was carried out in a topdown approach, and there was no map of conserved areas in the sub-watershed. In areas where contour plowing is widely practiced, Hurni (1985) suggested using $P$ values of 0.9 and 0.8 for agricultural and non-agricultural lands, respectively. Thus, we used a similar method in the present study to assign $P$ values to the study area for the baseline period (2017) and future scenario (2033). 

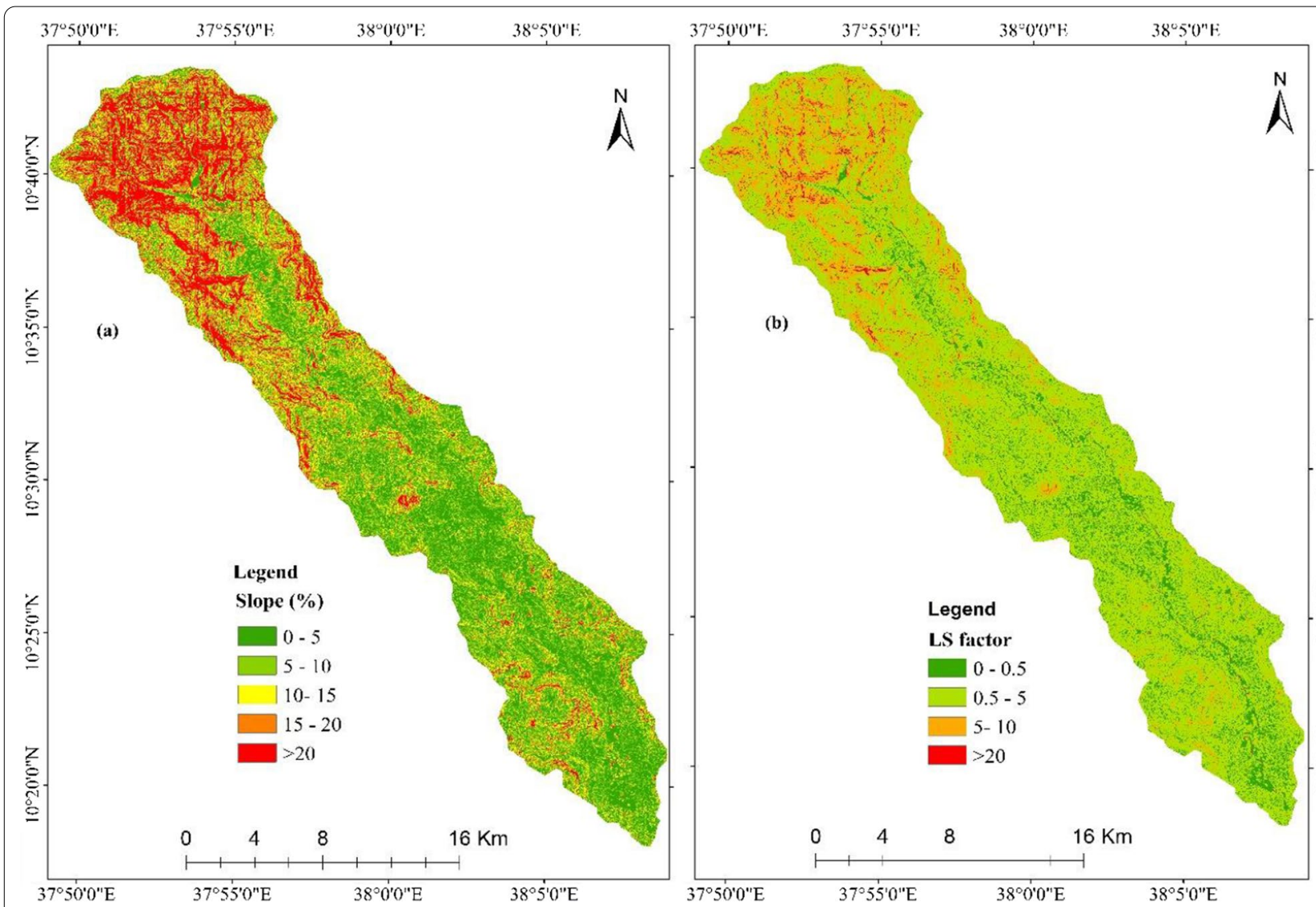

Fig. 5 Workflow of the methodology developed in this study

Finally, the annual soil loss was estimated on a cellby-cell basis of multiplying the five RUSLE factors using Eq. (1). As Landsat images and ASTER-DEM used in this study had $30 \mathrm{~m}$ spatial resolution, all the raster maps were resampled to $30 \times 30 \mathrm{~m}$ cell size and re-projected to UTM Zone $37^{\circ} \mathrm{N}$, WGS 1984 datum. Table 6 shows the $C$ values and the $P$ values derived from LULC information for the baseline and future period. The workflow of the methodology used in this study is shown in Fig. 5

\section{Results}

\section{Land use/land cover change in Muga watershed}

The produced LULC maps of the Muga watershed for the three reference years $(1985,2002$, and 2017) are presented in Fig. 6. The trend analysis made for the two consecutive periods, 1985-2002 and 2002-2017, showed spatiotemporal changes in LULC classes.

The magnitude and extent of LULC change for the study watershed between 1985 and 2017 were obtained from Belay and Mengistu (2019). The LULC change between 2017 and 2033 were calculated (Table 7). The predicted LULC map for 2033 is shown in Additional file 1 . As shown in LULC map of 2033, cultivated land remains a dominant land use type, which accounts for about $76.8 \%$ of the study watershed. From 2017 to 2033, the areal coverage of grassland decreased by $35.4 \%$, while urban area, shrub-bushland, forest, and cultivation area would increase by $2.9 \%, 10.4 \%, 6.8 \% 3.8 \%$, respectively. It should be noted that the decline of grassland area from 2017 to 2033 is probably due to the conversion of grasslands to cultivated land and shrub-bushland, as shown in Table 7.

\section{Future climate}

In Muga watershed, compared with 1985-2017 (1086.6 mm), the mean for RCMs ensemble (2018-2050) showed an increase in mean annual rainfall of $1272.9 \mathrm{~mm}$ (RCP4.5) and $1307.0 \mathrm{~mm}$ (RCP8.5). The result showed that the average rainfall erosivity is expected to increase from 602.6 MJ mm ha ${ }^{-1} \mathrm{~h}^{-1}$ year $^{-1}$ (1985-2017) to 707.3 and 726.4 MJ mm ha ${ }^{-1} \mathrm{~h}^{-1}$ year $^{-1}$ for the period 2018-2050, under RCP4.5 and RCP8.5, respectively. It is expected to increase by $17.15 \%$ and $20.27 \%$ under RCP 4.5 and RCP8.5, respectively. This result agrees with previous studies (Conway and Schipper 2011; Kassie et al. 


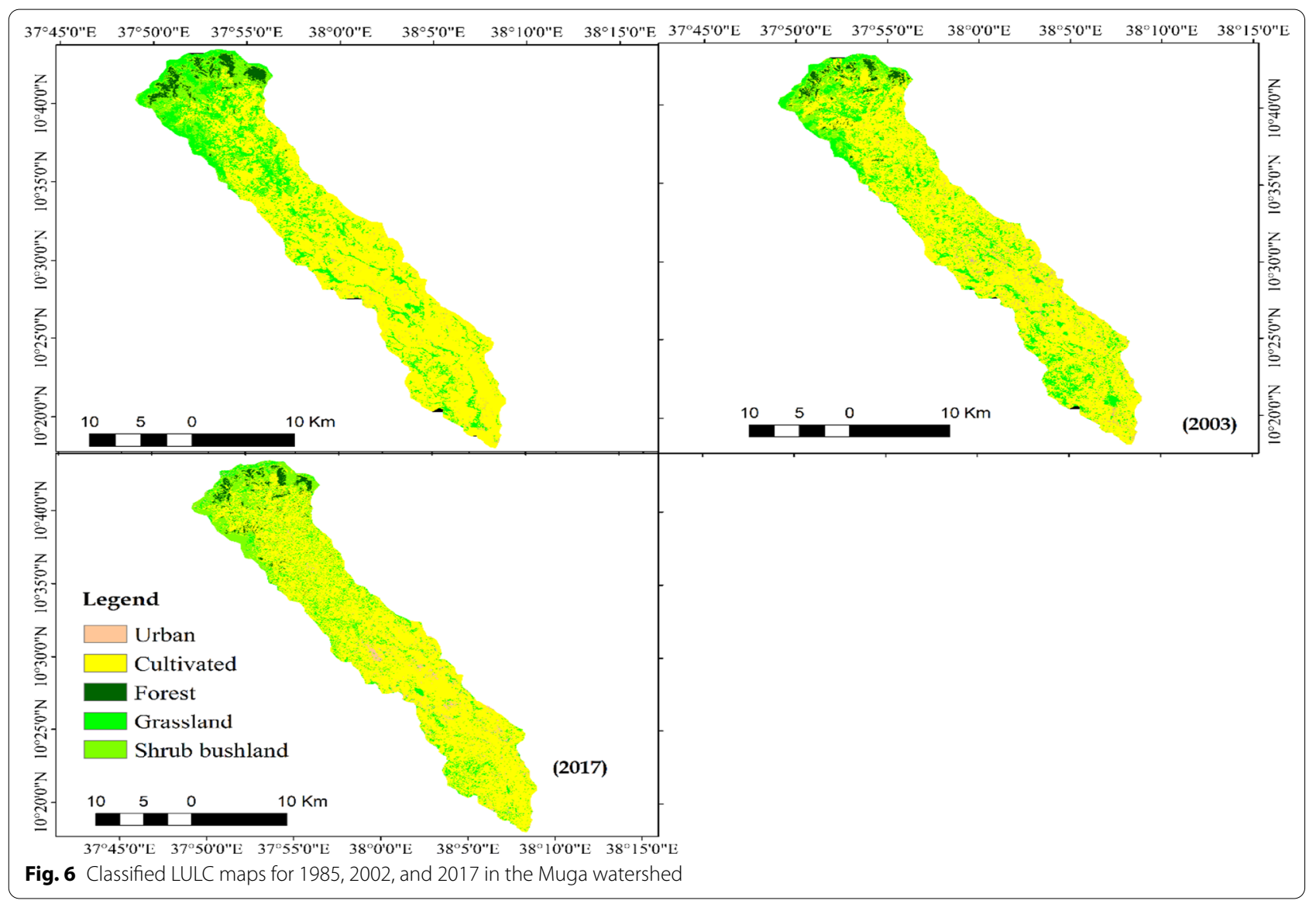

Table 7 Area and proportion of each land use categories in the Muga watershed

\begin{tabular}{|c|c|c|c|c|c|}
\hline & \multicolumn{2}{|c|}{ Reference (2017) } & \multicolumn{2}{|c|}{ Future (2033) } & \multirow{2}{*}{$\begin{array}{l}\text { Change } \\
\text { (2017- } \\
2033) \\
(\%)\end{array}$} \\
\hline & Area (ha) & $\%$ & Area (ha) & $\%$ & \\
\hline Grassland & 4862.7 & 11.4 & 3143.2 & 7.4 & -35.4 \\
\hline Cultivated land & $31,438.4$ & 74.0 & $32,624.7$ & 76.8 & 3.8 \\
\hline Urban area & 1008.7 & 2.4 & 1038.3 & 2.4 & 2.9 \\
\hline Forest & 1015.1 & 2.4 & 1084.2 & 2.6 & 6.8 \\
\hline Shrub-bushland & 4170.5 & 9.8 & 4605.0 & 10.8 & 10.4 \\
\hline Total area & $42,495.4$ & 100.0 & $42,495.4$ & 100.0 & \\
\hline
\end{tabular}

2014; Abera et al. 2018; Fentaw et al. 2018) that predicted increasing precipitation in other parts of Ethiopia.

\section{Impacts of land use/land cover changes on soil erosion}

LULC change in the area may increase or decrease soil erosion. The LULC dynamics of the Muga watershed from 1985 to 2017 was studied by Belay and Mengistu (2019). In the present study, to assess the impact of LULC change on soil erosion, the values of $C$ and $R$ factors were changed, while the other factors (i.e., soil erodibility, conservation practice factor, and slope length and slope steepness) kept constant.

The results of the study show that the average annual rate of soil erosion in the Muga watershed was increased from approximately $15 \mathrm{t} \mathrm{ha}^{-1}$ year $^{-1}$ in 1985 to $19 \mathrm{t} \mathrm{ha}^{-1}$ year $^{-1}$ in 2002 , and $19.7 \mathrm{t} \mathrm{ha}^{-1}$ year $^{-1}$ in 2017 (Table 8). The study results also indicate that if the LULC changes are not managed, the soil loss rate is expected to continue in 2033, which is expected to reach $20.7 \mathrm{t} \mathrm{ha}^{-1}$ year $^{-1}$ in 2033. Areas with soil erosion rates over $15 \mathrm{t} \mathrm{ha}^{-1}$ year $^{-1}$ during the study years were widely distributed on the upper and steep areas of the watershed, while those with an erosion rate of less than $10 \mathrm{t} \mathrm{ha}^{-1}$ year $^{-1}$ was mainly concentrated in the gentle areas of the lower and upper part of the watershed (Fig. 7). Increasing some types of LULC, such as cultivable land in steep areas and irrigated agriculture, will accelerate soil erosion by reducing soil cover in the future.

The validation and consistency of the model output was compared with the quantitative outputs of previous 
Table 8 Estimated mean annual soil erosion rate of each land use land cover type and the entire watershed in 1985, 2002, 2017, and 2033 in Muga watershed

\begin{tabular}{llllcrc}
\hline Year & \multicolumn{2}{l}{ Mean annual soil erosion rate $\left(\mathrm{t} \mathrm{ha}^{\mathbf{- 1}}\right.$ year $\left.^{-\mathbf{1}}\right)$} & & & \multicolumn{1}{c}{$\begin{array}{c}\text { Entire } \\
\text { watershed }\end{array}$} \\
\cline { 2 - 7 } & Grassland & Cultivated land & Urban area & Forest & Shrub-bushland \\
\hline 1985 & 8.0 & 18.0 & 11.0 & 3.0 & 7.5 & 15.0 \\
2002 & 12.0 & 19.0 & 12.0 & 8.5 & 12.0 & 19.0 \\
2017 & 14.2 & 21.7 & 10.4 & 11.2 & 11.9 & 19.7 \\
2033 & 13.6 & 25.0 & 6.5 & 9.1 & 13.0 & 20.7 \\
\hline
\end{tabular}

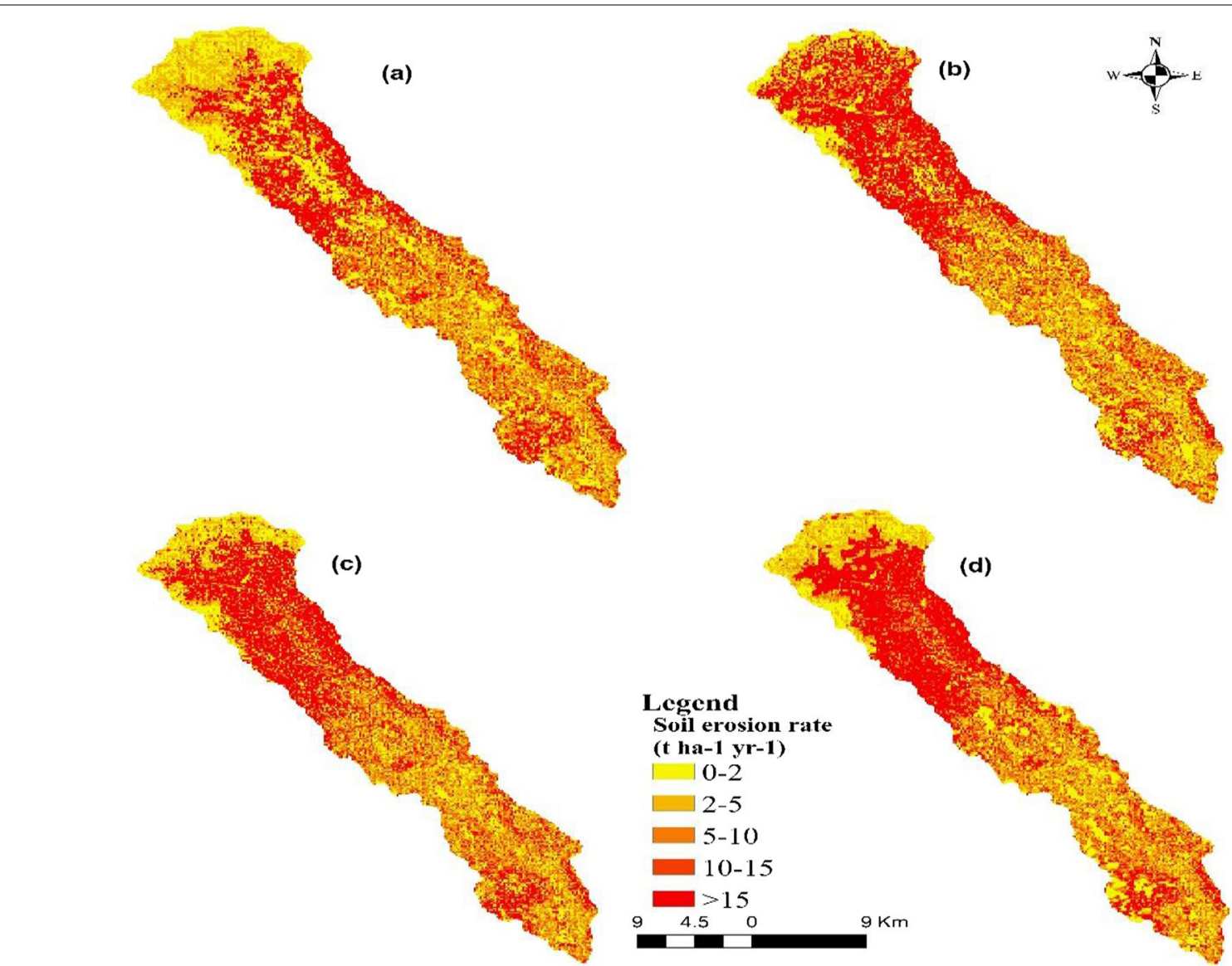

Fig. 7 Estimated annual soil loss map of the study area in 1985 (a), 2002 (b), 2017 (c), and 2033 (d)

experimental observations and similar empirical studies conducted in Ethiopia, mainly in the northwestern highlands. In addition, selected field observations were carried out. In supporting this process, the color printed model output soil erosion severity map was taken in the field to check the reality on the ground. Consequently, the estimated rate of soil loss and the spatial patterns are generally realistic as compared with the findings in the field and from the results of previous studies (Hurni 1983a, b, 1985; Bewket and Teferi 2009; Mengistu et al. 2015).

The relative contribution of each LULC type to soil erosion was assessed in the study watershed, and the result showed noticeable differences among LULC types in 1985, 2002, 2017, and 2033. The highest mean annual soil erosion rate was predicted on cultivated land (e.g., $18 \mathrm{t} \mathrm{ha}^{-1}$ year $^{-1}$ in 1985, $19 \mathrm{t} \mathrm{ha}^{-1}$ year $^{-1}$ in 2002, and $21.7 \mathrm{t} \mathrm{ha}^{-1}$ year $^{-1}$ 2017). 
Table 9 Annual soil erosion risk classes and area coverage under land use/land cover map of 198,2002, 2017, and 2033 in Muga watershed

\begin{tabular}{|c|c|c|c|c|c|c|c|c|}
\hline \multirow{3}{*}{$\begin{array}{l}\text { Soil erosion intensity class and rate } \\
\text { of soil loss }\end{array}$} & \multicolumn{8}{|c|}{ Study period } \\
\hline & \multicolumn{2}{|l|}{1985} & \multicolumn{2}{|l|}{2002} & \multicolumn{2}{|l|}{2017} & \multicolumn{2}{|l|}{2033} \\
\hline & Area (ha) & $\%$ & Area (ha) & $\%$ & Area (ha) & $\%$ & Area (ha) & $\%$ \\
\hline Low $\left(0-5\right.$ t ha $^{-1}$ year $\left.^{-1}\right)$ & $19,138.9$ & 45.0 & $18,343.9$ & 43.2 & $17,679.0$ & 41.6 & $17,412.5$ & 41.0 \\
\hline Moderate $\left(5-20\right.$ t ha $^{-1}$ year $\left.^{-1}\right)$ & $12,717.4$ & 29.0 & $12,217.4$ & 28.7 & $12,618.5$ & 29.7 & $12,205.5$ & 28.7 \\
\hline High (20-50 t ha ${ }^{-1}$ year $\left.^{-1}\right)$ & 6700.4 & 15.8 & 7051.3 & 16.6 & 6977.5 & 16.4 & 7437.1 & 17.5 \\
\hline Very high $\left(50-100\right.$ t ha $^{-1}$ year $\left.^{-1}\right)$ & 3148.6 & 7.4 & 3737.8 & 8.8 & 3972.3 & 9.3 & 4250.3 & 10.0 \\
\hline Severe (100-150 t ha ${ }^{-1}$ year $\left.^{-1}\right)$ & 529.5 & 1.2 & 814.5 & 1.9 & 834.9 & 2.0 & 783.6 & 1.8 \\
\hline Very severe $\left(>150 \mathrm{t} \mathrm{ha}^{-1}\right.$ year $\left.^{-1}\right)$ & 260.5 & 0.6 & 330.5 & 0.8 & 413.2 & 1.0 & 406.4 & 1.0 \\
\hline
\end{tabular}

Although the area under cultivation is expected to decrease by 2033 , the average annual rate of soil erosion is expected to be higher than 1985, 2002, and 2017. The causes of the higher soil loss estimated from cultivated land may be related to the encroachments of sloping plowing in mountainous areas of the watershed, as the expense of expansion of urban areas into cultivation. The results of this study suggest that the rate of soil loss in shrub-bushland areas will be higher than in grassland and urban area in the future (2033), which may be due to the scanty vegetation and the steepness of the area, where the shrub-bushland area is located. This indicates that in the year 2033, the area of shrub-bushland is expected to have less capability to protect the soil from erosion than in the year 2017. Thus, future LULU changes under the business as usual scenario, with increasing LULC changes in the study area (i.e., expansion of cultivated land) contributing to more soil erosion, which is anticipated to increase further with higher precipitation. It is estimated that in 2033 there will be higher rates of soil erosion in cultivated, followed by grassland and shrubbushland, which are the key areas to prevent soil erosion in the Muga watershed in the future.

As shown in Fig. 7 and Table 9, the percentage areas under low to medium-level soil erosion were decreased between 1985 and 2033. In contrast, the portion of areas under high and very high soil erosion classes was increased during the same periods, but this change is relatively low. The increase in the areas with high and very high soil erosion rates between 1985 and 2033 may be due to the conversion of some parts of the watershed with low and moderate erosion classes into the range of high and very high erosion. Between 1985 and 2017, there was an upward trend in the area occupied by severe and very severe erosion classes, while the severe erosion category is expected to decline in 2033. It was also found that the area classified as very severe erosion is uniform in 2017 and 2033.
Table 10 Annual soil erosion risk classes and area coverage under RCP4.5 and RCP8.5 in Muga watershed

\begin{tabular}{|c|c|c|c|c|}
\hline \multirow{2}{*}{$\begin{array}{l}\text { Soil severity categories and } \\
\text { rate of soil erosion }\end{array}$} & \multicolumn{2}{|c|}{2050 (RCP4.5) } & \multicolumn{2}{|c|}{2050 (RCP8.5) } \\
\hline & Area (ha) & $\%$ & Area (ha) & $\%$ \\
\hline Low $\left(0-5\right.$ t ha $^{-1}$ year $\left.^{-1}\right)$ & $15,904.1$ & 37.4 & $15,526.2$ & 36.5 \\
\hline Moderate $\left(5-20\right.$ t ha $^{-1}$ year $\left.^{-1}\right)$ & $13,677.6$ & 32.2 & $13,864.7$ & 32.6 \\
\hline High $\left(20-50\right.$ t ha $^{-1}$ year $\left.^{-1}\right)$ & 7041.0 & 16.6 & 7097.8 & 16.7 \\
\hline Very high (50-100 t ha ${ }^{-1}$ year $^{-1}$ ) & 4273.5 & 10.1 & 4346.7 & 10.2 \\
\hline Severe (100-150 t ha ${ }^{-1}$ year $\left.^{-1}\right)$ & 1083.5 & 2.5 & 1136.0 & 2.7 \\
\hline Very severe $\left(>150\right.$ t ha $^{-1}$ year $\left.^{-1}\right)$ & 515.9 & 1.2 & 524.2 & 1.2 \\
\hline Total area & $42,495.4$ & 100.0 & $42,495.4$ & 100.0 \\
\hline
\end{tabular}

\section{Impacts of climate change on soil erosion}

Rainfall amount and rainfall erosivity under RCP4.5 and RCP8.5 for the study area showed an increasing trend, which is anticipated to affect soil loss negatively. Increasing rainfall will lead to an increase in annual rainfall erosivity, which increases the annual rate of soil loss. Thus we analyzed the average annual rate of soil erosion from the watershed by modifying climatic data during the study period to assess the relationship between soil erosion and climate change in 2017 and 2050.

In this study, we simulated the future rate of soil erosion due to changes in climatic conditions that may increase the risk of soil and land degradation in the Muga watershed, which can also affect agricultural productivity and livelihoods of the local community. The results are shown in Table 10 and Fig. 8. The results show that the average annual rate of soil loss in the Muga watershed in 2050 under RCP4.5 and RCP8.5 will be $21.6 \mathrm{t} \mathrm{ha}^{-1}$ year $^{-1}$ and $22.2 \mathrm{t} \mathrm{ha}^{-1} \mathrm{year}^{-1}$, respectively, which is equivalent to an annual soil loss of 917,900.6 $\mathrm{t} \mathrm{year}^{-1}$ and $960,396.0 \mathrm{t} \mathrm{year}^{-1}$, respectively. Therefore, the rate of soil erosion is predicted to increase by $9.7 \%$ and $12.7 \%$ under RCP4.5 and RCP8.5, respectively, compared to the reference period. This means that the mean annual soil 


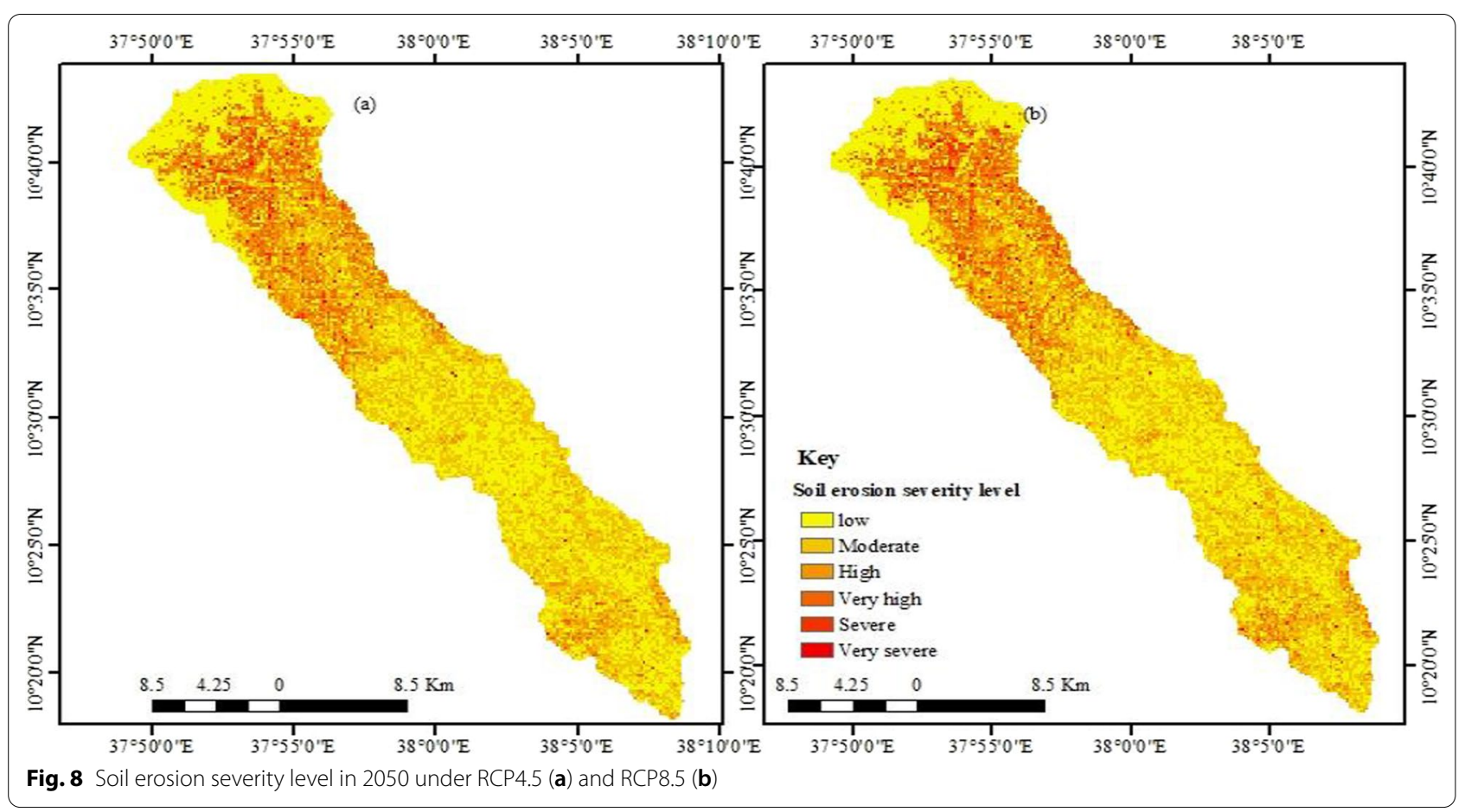

erosion rate in the Muga watershed showed an increasing trend in the future compared to the reference period due to climate change.

Recognizing the soil loss response helps to know the rate of soil erosion changes with climate change, which helps to identify priority areas for implementing soil management measures in the study watershed. Increased soil erosion due to climate changes can affect the watershed's local ecosystems and can cause hydrological changes in streams originating from the watershed.

Comparing LULC and climate change, as shown in Table 11, climate changes are expected to have a higher impact on soil erosion than LULC change in the future. Figure 8 shows a map of soil erosion in the Muga watershed in 2050 by averaging six RCMs under RCP4.5 and RCP8.5. The figures show that high soil losses are concentrated on the watershed's upper escarpment, where cultivation and other human activities are carried out on the steep slopes of Choke Mountain.

\section{Combined impacts of future land use/land cover and climate change on soil erosion}

In addition to assessing the individual impacts of future LULC and climate change, the combined and synergistic effects of these changes on soil erosion were also evaluated in the Muga watershed. By replacing the two factors of rainfall erosivity $(R)$ and cover management factor $(C)$, and keeping all other factors constant in the RUSLE model, soil erosion was predicted using future LULC and climate change scenarios: 2033 LULC map and climate scenarios under RCP4.5 and RCP8.5 in 2050. The magnitudes and rates of mean annual loss of soil under future LULC and climate change scenarios are presented in Table 11.

The highest soil erosion rate for the study watershed is predicted when LULC change is combined with climate change under the RCP8.5 scenario, which is estimated about $22.8 \mathrm{t} \mathrm{ha}^{-1}$ year $^{-1}$. Similarly, the average annual rate of soil loss under RCP4.5 is estimated about $21.6 \mathrm{t} \mathrm{ha}^{-1}$ year $^{-1}$. Therefore, changes in LULC under RCP4.5 and RCP8.5 scenarios showed a slight variation in annual soil loss rates. It should also be noted that the ranges of relative change in average annual soil loss rates for the future period due to climate change are larger than LULC change. Table 11 shows that soil erosion in the Muga watershed appears to be more sensitive to future climate changes than future LULC changes. The magnitude of the soil loss rates is expected to increase in the future due to the synergy effects of climate and LULC changes. As it is shown in Table 11, the combined effects of LULC and climate change on soil loss rate are expected to increase in the future period.

LULC changes are expected to exacerbate the rate of soil loss by $5 \%$, while climate change is also predicted to increase the rate of soil loss by approximately $9.7 \%$ and $12.7 \%$ under RCP4.5 and RCP8.5, respectively. When LULC and climate change act together, the average annual soil loss rate increases to $13.2 \%$ and $15.7 \%$ under 
Table 11 Mean annual soil loss ( $\mathrm{t} \mathrm{ha}^{-1}$ year ${ }^{-1}$ ) of Muga watershed under current and future land use/land cover and climate

\begin{tabular}{lllllll}
\hline Model input & (a) & (b) & (c) & (d) & (e) & (f) \\
\hline LULC & 2017 & 2033 & 2033 & 2033 & 2017 & 2017 \\
Climate & $1985-2017$ & $1985-2017$ & RCP 4.5 (2018- & RCP 8.5 (2018- & RCP 4.5 (2018- & RCP 8.5 \\
& & & $2050)$ & $2050)$ & $2018-$ \\
$2050)$ & 22.6 & 22.2 \\
$\begin{array}{l}\text { Mean annual soil erosion } \\
\text { (t ha } \text { year }^{-1} \text { ) }\end{array}$ & 19.7 & 20.7 & 22.3 & 22.8 & 21.6 \\
\hline
\end{tabular}

(a) Baseline period (land use/land cover in 2017 and baseline climate), (b) impacts of land use/land cover change, (c) combined impacts of future land use/land cover (2033) and climate change under RCP4.5, (d) combined impacts of future land useland cover and climate change under RCP8.5, (e) only impacts of future climate change under RCP4.5, (f) only impacts of climate change under RCP8.5

RCP4.5 and RCP8.5, respectively, which is higher than the individual effects of LULC and climate change. Thus, the combination of modeled LULC and climate change is expected to have a substantial impact on soil erosion in the future. Increasing average annual soil erosion rates caused by LULC and climate change will significantly impact land use planning and implementation in the Muga watershed. Besides, as the LULC types change, adverse effects may be intensified.

\section{Discussion}

Soil erosion prevention patterns varied considerably depending on location and time. Globally, as environmental change accelerates, more frequent and intense changes in LULC associated with a higher frequency of extreme climate events will increase soil degradation and make the ecosystem less resilient to natural disturbance (Cramer et al. 2018; Guerra et al. 2020). The results of the study show a spatial and temporal variability in soil erosion rate due to climate dynamics and changes in LULC. According to Zhou et al. (2008), a soil vegetation cover of more than $78 \%$ greatly reduce erosion by water. The results of this study show that less than $5 \%$ of the study watershed is covered with forest; hence, the study watershed is sensitive to soil erosion. Furthermore, the expansion of cropland at the expense of forest and shrubland reduced the protection and soil organic matter of the soil and exposed it to the impact of climate change thereby accelerated soil erosion rate (Wijitkosum 2012).

The results of future climate projection showed that the mean annual precipitation in the watershed is expected to increase by $17.15 \%$ and $20.27 \%$ under RCP4.5 and RCP8.5, respectively, compared to the historical period of 1985-2017. This result agrees with previous studies (e.g., Conway and Schipper 2011; Kassie et al. 2014; Abera et al. 2018; Fentaw et al. 2018) that predicted the increase in precipitation in the other parts of Ethiopia.

Muga watershed also showed significant dynamics in LULC from 1985 to 2017. The results of the study show that LULC changes played a significant role in increasing the soil erosion rate in the study watershed. This finding coincides with previous research conducted in the Upper Blue Nile basin (e.g., Gessesse et al. 2015; Gelagay and Minale 2016; Moges and Bhat 2017; Tadesse et al. 2017), who reported that LULC change was a responsible factor for the increased soil erosion in their respective study areas.

Table 8 shows the estimated soil loss in 1985, 2002, 2018, and 2033. The estimated average soil loss was increased due to LULC dynamics that occurred between 1985 and 2017. This shows that LULC has a significant impact on soil loss by water erosion. The results of this study show that the average annual rate of soil loss in the Muga watershed (19.0 t ha year $^{-1}$ in 2002, $19.7 \mathrm{t} \mathrm{ha}^{-1}$ year $^{-1}$ in 2017, and $20.7 \mathrm{t} \mathrm{ha}^{-1}$ year $^{-1}$ in 2033) was substantially higher than the average soil loss of Upper Blue Nile basin $\left(16 \mathrm{t} \mathrm{h}^{-1}\right.$ year $\left.^{-1}\right)$ reported by Mengistu et al. (2015), and Fenta et al. (2021) who reported $16.5 \mathrm{t} \mathrm{ha}^{-1}$ year $^{-1}$ average soil loss rate for Ethiopia.

This study also shows that about $25 \%$ of the study watershed has a soil loss rate of $20 \mathrm{t} \mathrm{ha}^{-1}$ year $^{-1}$ and above, which is higher than the tolerable soil loss limits estimated for Ethiopia. Tolerable soil loss rates suggested for Ethiopia is $12 \mathrm{t} \mathrm{ha}^{-1}$ year $^{-1}$ (Hurni 1983b). According to Khosrokhani and Pradhan (2014), the rate of soil formation in tropical areas is generally slow, and soil loss of more than $1 \mathrm{t} \mathrm{ha}^{-1}$ year $^{-1}$ is regarded as irreversible soil erosion. However, soil loss of $1 \mathrm{t} \mathrm{ha}^{-1}$ year $^{-1}$ or less is considered as an acceptable soil erosion rate. The predicted average soil loss for the study year exceeds the tolerable soil erosion rates of $12 \mathrm{t} \mathrm{ha}^{-1}$ year $^{-1}$ and the estimated soil formation rate of $2 \mathrm{t} \mathrm{ha}^{-1}$ year $^{-1}$ for Ethiopia (Hurni 1983b), which can affect soil productivity.

In the presents study, the average annual rate of soil loss varies with LULC types, with cultivated land being the main contributor (about $18 \mathrm{t} \mathrm{ha}^{-1}$ year $^{-1}$ in 1985, $19 \mathrm{t} \mathrm{ha}^{-1}$ year $^{-1}$ in 2002, and $21.7 \mathrm{t} \mathrm{ha}^{-1}$ year $^{-1}$ in 2017), followed by grasslands and shrub-bushlands (Table 8). The lowest soil loss rates were observed in forest and 
urban areas (Table 8). This is due to vegetation cover and the corresponding low $C$-factor values (Zhou et al. 2008). The highest rates of soil loss on cultivated land indicated that land conversion from natural vegetation (e.g., forest and shrub-bushland) to cultivated land would exacerbate land degradation due to soil erosion.

Similarly, Fenta et al. (2021) estimated an average annual soil loss rate of $36.4 \mathrm{t} \mathrm{ha}^{-1}$ year $^{-1}$ from cultivated land for Ethiopia's highlands. This is twice the overall average rate of soil loss $\left(16.5 \mathrm{tha}^{-1}\right.$ year $\left.^{-1}\right)$, they reported for the whole highlands of Ethiopia. Contrary to our research results, Taye et al. (2018) reported the highest soil loss rate of $38.7 \mathrm{t} \mathrm{ha}^{-1}$ year $^{-1}$ from grassland compared with $7.2 \mathrm{t} \mathrm{ha}^{-1}$ year $^{-1}$ from cropland.

Studies showed that rainfall is one of the most sensitive factors for soil erosion (Zhang and Nearing 2005; Her et al. 2019; Berberoglu et al. 2020; Borrelli et al. 2020; Ciampalini et al. 2020; Eekhout and De Vente 2020). The present study results show an increase in the future period's annual rainfall erosivity compared to the baseline. The RCP8.5 scenario is expected to have the highest amount of erosivity factor and will have the highest erosion rate, followed by RCP4.5 in 2018-2050. The rate of soil erosion under RCP 4.5 and RCP8.5 is expected to increase by $9.7 \%$ and $12.7 \%$, respectively, compared to the baseline period.

The spatial distribution of soil erosion in the Muga watershed is shown in Fig. 8. As shown in Table 8, the areas with moderate and very high-intensity soil erosion rate are mainly occupied in the study watershed, ranging from $19.7 \mathrm{t} \mathrm{ha}^{-1}$ year $^{-1}$ under LULC of 2017 and climate of 1985-2017 to $22.3 \mathrm{t} \mathrm{ha}^{-1}$ year $^{-1}$ under LULC of 2033 and RCP4.5 and $22.8 \mathrm{t} \mathrm{ha}^{-1}$ year $^{-1}$ under LULC of 2033 and RCP 8.5 , respectively.

The results of this study are consistent with the results in the Upper Blue Nile basin of Ethiopia (e.g., Bewket and Teferi 2009; Mengistu et al. 2015). However, the rate of soil erosion in the study area is lower than the value previously reported by Yesuph and Dagnaw (2019) for Beshillo catchment of the Blue Nile Basin, Ethiopia, which is $37 \mathrm{t} \mathrm{ha}^{-1}$ year $^{-1}$. According to Kouli et al. (2009), soil loss rates above $10 \mathrm{t} \mathrm{ha}^{-1}$ year $^{-1}$ will not reverse for 50 to 100 years. Considering this threshold, the total area of the study watershed, where the risk of soil erosion exceeds the soil loss tolerance is expected to be 19,348 ha and 21,057 ha in the 2050s under RCP4.5 and RCP8.5, respectively.

The future scenario shows that LULC combined with climate change substantially increases the average soil erosion by 2070s globally (Borrelli et al. 2020). The results of this study also showed that when projected land use is combined with simulated climate change, the mean annual soil erosion rate is expected to increase by $13.2 \%$ under LULC map of 2033 and RCP4.5 and 15.7\% under
LULC map of 2033 and RCP8.5 compared with the baseline.

The results of this study showed that the trend of soil erosion increased during the years of study and is expected to continue in the future due to LULC and climate change. As a result, it affects agricultural productivity and hydrological process in the study watershed. Thus, there should be appropriate land management strategies that take into account the future LULC and climate change to manage these ecological processes, because the LULC and climate change have a profound impact on the ecosystem of the Muga basin.

\section{Conclusion}

The study demostrated the impacts of LULC and climate changes on soil erosion using an integrated approach of CA-Markov chain, climate and soil erosion models. The outcomes indicate that soil erosion rate in the Muga watershed shows an increasing trend from $19.7 \mathrm{t} \mathrm{ha}^{-1}$ year $^{-1}$ in 2017 to $20.7 \mathrm{t} \mathrm{ha}^{-1}$ year $^{-1}$ in 2033 due to LULC change. Furthermore, by the 2050s, the rainfall erosivity factor may increase, which can lead to more soil erosion rate. Hence, the soil loss rate in Muga watershed is projected to increase to $22.0 \mathrm{t} \mathrm{ha}^{-1}$ year $^{-1}$ and $22.8 \mathrm{tha}^{-1}$ year $^{-1}$ under RCP4.5 and RCP8.5 scenarios, respectively, due to higher erosive power of the future intense rainfall. When the combined effect of LULC and climate change considered, the average annual soil loss rate was increased by $13.2 \%$ and $15.7 \%$ under RCP 4.5 and RCP8.5, respectively, which is much higher than the individual effects of LULC and climate change. The change in soil erosion rate showed a spatial variation, hence the upper escarpment of the watershed which consists of steep slopes is highly vulnerable to soil erosion hazard.

The outcome of this investigation would be imperative in the decision and implementation of appropriate soil and water conservation methods and local climate adaption strategies within the study area and for deducing the changes in the future. Likewise, the results obtained from this study can be used by local and regional government agencies, developers and policymakers to diminish the rate of soil loss in the study watershed. Integrated use of CA-Markov chain, climate, and soil erosion models have demonstrated to provide relevant information about the impacts of LULC and climate change on soil erosion at a watershed level.

\section{Abbreviations}

LULC: Land use/land cover; CA: Cellular automata; CSA: Central Statistical Agency; DEM: Digital elevation model; EMA: National Metrological Agency; MCE: Multi-criteria evaluation; RCP: Representative concentration pathways; RUSLE: Revised Universal Soil Loss Equation; MoWIE: Ministry of Water, Irrigation, and Electricity; RCM: Regional climate model; ETM: Enhanced Thematic 
Mapper Plus; TM: Thematic Mapper; AHP: Analytical hierarchy processes; WOA: Weighted overlay analysis; CMIP5: Coupled Model Intercomparison Phase 5; OLI: Operational Land Imagery; USGS: United States Geological Survey; CORDEX: Coordinated Regional Downscaling Experiment.

\section{Supplementary Information}

The online version contains supplementary material available at https://doi. org/10.1186/s13717-021-00339-9.

Additional file 1: Fig. S1. Land use land cover map of Muga watershed for 2017 (A) and 2033 (B). Fig. S2. Standardized biophysical factors of LULC in the study area. (a) Elevation, (b) proximity to a stream, (c) slope, (d) proximity to road, (e) proximity to urban, (f) proximity to shrub-bushland, (g) proximity to cultivation, (h) proximity to grassland, (i) proximity to forest.

\section{Acknowledgements}

The financial support granted to the first author from the International Foundation for Science (IFS) in Sweden is gratefully acknowledged (Grant No. W_6250-1, January 2019). The authors would like to thank Bahir Dar University and Debre Tabor University in Ethiopia for their financial support. We would like to acknowledge Ethiopian Meteorological Agency for providing meteorological data. We are also very grateful to the local communities in the study watersheds, the agricultural development agents for their support during the fieldwork.

\section{Authors' contributions}

TB has made a significant contribution to the conception and designing of the study, data collection, data analysis, interpretation of the results, and prepared the manuscript. DAM has contributed to supervising the research, analysis of the research, and suggesting ideas in the manuscript preparation process. All authors read and approved the final manuscript.

\section{Funding}

The International Foundation for Science had funded this research (IFS) (Grant No. W_6250-1, January 2019) and Bahir Dar University.

\section{Availability of data and materials}

The data sets used and analyzed during the current study are available from the corresponding author on reasonable request.

\section{Declarations}

Ethics approval and consent to participate

Not applicable.

\section{Consent for publication}

All authors agreed and approved the manuscript for publication in Ecological Processes.

\section{Competing interests}

The authors declare that they have no competing interests.

\section{Author details}

'Department of Geography and Environmental Studies, Debre Tabor University, Debra Tabor, Ethiopia. ${ }^{2}$ Department of Geography and Environmental Studies, Bahir Dar University, Bahir Dar, Ethiopia. ${ }^{3}$ Geospatial Data and Technology Center, Bahir Dar University, Bahir Dar, Ethiopia.

Received: 9 December 2020 Accepted: 2 June 2021

Published online: 01 November 2021

\section{References}

Abera K, Crespo O, Seid J, Mequanent F (2018) Simulating the impact of climate change on maize production in Ethiopia, East Africa. Environ Syst Res 7(1):4. https://doi.org/10.1186/s40068-018-0107-z
Addis HK, Klik A (2015) Predicting the spatial distribution of soil erodibility factor using USLE nomograph in an agricultural watershed, Ethiopia. Int Soil Water Conserv Res 3(4):282-290

Adugna A, Abegaz A (2016) Effects of land use changes on the dynamics of selected soil properties in northeast Wellega, Ethiopia. Soil 2(1):63-70

Adugna A, Abegaz A, Cerdà A (2015) Soil erosion assessment and control in Northeast Wollega, Ethiopia. Solid Earth Discuss 7(4):3511-3540

Alemseged TH, Tom R (2015) Evaluation of regional climate model simulations of rainfall over the Upper Blue Nile basin. Atmos Res 161:57-64

Al-Sharif AA, Pradhan B (2014) Monitoring and predicting land use change in Tripoli Metropolitan City using an integrated Markov chain and cellular automata models in GIS. Arab J Geosci 7(10):4291-4301

Amundson R, Berhe AA, Hopmans JW, Olson C, Sztein AE, Sparks DL (2015) Soil and human security in the 21st century. Science 348(6235):1261071. https://doi.org/10.1126/science.1261071

Anache JA, Flanagan DC, Srivastava A, Wendland EC (2018) Land use and climate change impacts on runoff and soil erosion at the hillslope scale in the Brazilian Cerrado. Sci Total Environ 622:140-151

Aneseyee AB, Elias E, Soromessa T, Feyisa GL (2020) Land use/land cover change effect on soil erosion and sediment delivery in the Winike watershed, Omo Gibe Basin, Ethiopia. Sci Total Environ 728:138776. https://doi.org/10.1016/j.scitotenv.2020.138776

Angima SD, Stott DE, O'neill MK, Ong CK, Weesies GA (2003) Soil erosion prediction using RUSLE for central Kenyan highland conditions. Agric Ecosyst Environ 97(13):295-308

Araya YH, Cabral P (2010) Analysis and modeling of urban land cover change in Setúbal and Sesimbra, Portugal. Remote Sens 2(6):1549-1563

Arsanjani JJ, Helbich M, de Noronha Vaz E (2013) Spatiotemporal simulation of urban growth patterns using agent-based modeling: the case of Tehran. Cities 32:33-42

Belay T, Mengistu D (2019) Land use and land cover dynamics and drivers in the Muga watershed, Upper Blue Nile basin, Ethiopia. Remote Sens Appl Soc Environ 15:100249

Belihu M, Tekleab S, Abate B, Bewket W (2020) Hydrologic response to land use land cover change in the upper Gidabo watershed, Rift Valley Lakes Basin, Ethiopia. HydroResearch 3:85-94

Berberoglu S, Cilek A, Kirkby M, Irvine B, Donmez C (2020) Spatial and temporal evaluation of soil erosion in Turkey under climate change scenarios using the Pan-European Soil Erosion Risk Assessment (PESERA) model. Environ Monit Assess 192(8):491

Berihun ML, Tsunekawa A, Haregeweyn N, Meshesha DT, Adgo E, Tsubo M, Masunaga T, Fenta AA, Sultan D, Yibeltal M, Ebabu K (2019) Hydrological responses to land use/land cover change and climate variability in contrasting agro-ecological environments of the Upper Blue Nile basin, Ethiopia. Sci Total Environ 689:347-365. https://doi.org/10.1016/j.scito tenv.2019.06.338

Bewket W, Teferi E (2009) Assessment of soil erosion hazard and prioritization for treatment at the watershed level: case study in the Chemoga watershed, Blue Nile basin, Ethiopia. Land Degrad Dev 20(6):609-622

Borrelli P, Robinson DA, Panagos P, Lugato E, Yang JE, Alewell C, Wuepper D, Montanarella L, Ballabio C (2020) Land use and climate change impacts on global soil erosion by water (2015-2070). Proc Natl Acad Sci 117(36):21994-22001. https://doi.org/10.1073/pnas.2001403117

Chen J, Brissette FP, Lucas-Picher P (2016) Transferability of optimally-selected climate models in the quantification of climate change impacts on hydrology. Clim Dyn 47(9-10):3359-3372

Chimdessa K, Quraishi S, Kebede A, Alamirew T (2019) Effect of land use land cover and climate change on river flow and soil loss in Didessa River Basin, South West Blue Nile Ethiopia. Hydrology 6(1):2

Christensen JH, Boberg F, Christensen OB, Lucas-Picher P (2008) On the need for bias correction of regional climate change projections of temperature and precipitation. Geophys Res Lett 35(20):L20709

Ciampalini R, Constantine JA, Walker-Springett KJ, Hales TC, Ormerod SJ, Hal IR (2020) Modelling soil erosion responses to climate change in three catchments of Great Britain. Sci Total Environ 749:141657. https://doi. org/10.1016/j.scitotenv.2020.141657

Congalton RG, Green K (2019) Assessing the accuracy of remotely sensed data: principles and practices. CRC Press, Boca Raton

Conway D, Schipper ELF (2011) Adaptation to climate change in Africa: challenges and opportunities identified from Ethiopia. Glob Environ 
Chang 21(1):227-237. https://doi.org/10.1016/j.gloenvcha.2010.07. 013

Cramer W, Guiot J, Fader M, Garrabou J, Gattuso J-P, Iglesias A, Lange MA, Lionello P, Llasat MC, Paz S, Peñuelas J, Snoussi M, Toreti A, Tsimplis MN, Xoplaki E (2018) Climate change and interconnected risks to sustainable development in the Mediterranean. Nat Clim Chang 8(11):972-980. https://doi.org/10.1038/s41558-018-0299-2

Crewett W, Bogale A, Korf B (2008) Land tenure in Ethiopia: continuity and change, shifting rulers, and the quest for state control. CAPRi Working Paper 91. International Food Policy Research Institute, Washington, $\mathrm{DC}$

de Hipt FO, Diekkrüger B, Steup G, Yira Y, Hoffmann T, Rode M, Näschen K (2019) Modeling the effect of land use and climate change on water resources and soil erosion in a tropical West African catchment (Dano, Burkina Faso) using SHETRAN. Sci Total Environ 653:431-445

de Oliveira Barros K, Ribeiro CAAS, Marcatti GE, Lorenzon AS, de Castro NLM, Domingues GF, de Carvalho JR, dos Santos AR (2018) Markov chains and cellular automata to predict environments subject to desertification. J Environ Manage 225:160-167

Demessie ET (2015) Soil hydrological impacts and climatic controls of land use and land cover changes in the Upper Blue Nile (Abay) basin. CRC Press, Boca Raton

Deng Z, Zhang X, Li D, Pan G (2015) Simulation of land use/land cover change and its effects on the hydrological characteristics of the upper reaches of the Hanjiang Basin. Environ Earth Sci 73(3):1119-1132

Desmet PJJ, Govers G (1996) A GIS procedure for automatically calculating the USLE LS factor on topographically complex landscape units. J Soil Water Conserv 51(5):427-433

Duarte L, Teodoro AC, Gonçalves JA, Soares D, Cunha M (2016) Assessing soil erosion risk using RUSLE through a GIS open source desktop and web application. Environ Monit Assess 188(6):351

Eastman JR (2012) IDRISI Selva manual, version 17. Clark University, Worcester, p 322

Ebabu K, Tsunekawa A, Haregeweyn N, Adgo E, Meshesha DT, Aklog D, Masunaga T, Tsubo M, Sultan D, Fenta AA (2019) Effects of land use and sustainable land management practices on runoff and soil loss in the Upper Blue Nile basin, Ethiopia. Sci Total Environ 648:1462-1475

BCEOM (1998) Abbay River Basin Integrated Development Master Plan Project, Phase 2, Data Collection and Site-Investigation Survey and Analysis, Section II. Section II. Sectoral Studies, vol. XIV

Eekhout JP, De Vente J (2020) How soil erosion model conceptualization affects soil loss projections under climate change. Progr Phys Geogr Earth Environ 44(2):212-232. https://doi.org/10.1177/0309133319 871937

Fenta AA, Yasuda H, Shimizu K, Haregeweyn N, Negussie A (2016) Dynamics of soil erosion as influenced by watershed management practices: a case study of the Agula watershed in the semi-arid highlands of northern Ethiopia. Environ Manage 58(5):889-905

Fenta AA, Tsunekawa A, Haregeweyn N, Tsubo M, Yasuda H, Kawai T, Ebabu K, Berihun ML, Belay AS, Sultan D (2021) Agroecology-based soil erosion assessment for better conservation planning in Ethiopian river basins. Environ Res 195:110786

Fentaw F, Hailu D, Nigussie A, Melesse AM (2018) Climate change impact on the hydrology of Tekeze Basin, Ethiopia: projection of rainfall-runoff for future water resources planning. Water Conserv Sci Eng 3(4):267-278. https://doi.org/10.1007/s41101-018-0057-3

Ferreira V, Panagopoulos T, Cakula A, Andrade R, Arvela A (2015) Predicting soil erosion after land use changes for irrigating agriculture in a large reservoir of southern Portugal. Agric Agric Sci Procedia 4:40-49

Fick SE, Hijmans RJ (2017) WorldClim 2: new 1-km spatial resolution climate surfaces for global land areas. Int J Climatol 37(12):4302-4315

Field CB, Barros VR (2014) Climate change 2014-impacts, adaptation and vulnerability: regional aspects. Cambridge University Press, Cambridge

Fitawok MB, Derudder B, Minale AS, Van Passel S, Adgo E, Nyssen J (2020) Modeling the impact of urbanization on land-use change in Bahir Dar City, Ethiopia: an integrated cellular Automata-Markov Chain Approach. Land 9(4):115

Ganasri BP, Ramesh H (2016) Assessment of soil erosion by RUSLE model using remote sensing and GIS - a case study of Nethravathi Basin. Geosci Front 7(6):953-961
Gashaw T, Tulu T, Argaw M, Worqlul AW (2018) Modeling the hydrological impacts of land use/land cover changes in the Andassa watershed, Blue Nile Basin, Ethiopia. Sci Total Environ 619:1394-1408

Gebre SL, Ludwig F (2015) Hydrological response to climate change of the upper blue Nile River Basin: based on IPCC fifth assessment report (AR5). J Climatol Weather Forecast 3(1):1-15

Gelagay HS, Minale AS (2016) Soil loss estimation using GIS and remote sensing techniques: a case of Koga watershed, Northwestern Ethiopia. Int Soil Water Conserv Res 4(2):126-136

Gelete G, Gokcekus H, Gichamo T (2019) Impact of climate change on the hydrology of Blue Nile basin, Ethiopia: a review. J Water Clim Change 11:1539-1550

Gessesse B, Bewket W, Bräuning A (2015) Model-based characterization and monitoring of runoff and soil erosion in response to land use/land cover changes in the Modjo watershed, Ethiopia. Land Degrad Dev 26(7):711-724

Gidey E, Dikinya O, Sebego R, Segosebe E, Zenebe A (2017) Cellular automata and Markov Chain (CA_Markov) model-based predictions of future land use and land cover scenarios (2015-2033) in Raya, northern Ethiopia. Model Earth Syst Environ 3(4):1245-1262

Giri S, Nejadhashemi AP, Zhang Z, Woznicki SA (2015) Integrating statistical and hydrological models to identify implementation sites for agricultural conservation practices. Environ Model Softw 72:327-340

Guerra CA, Rosa IMD, Valentini E, Wolf F, Filipponi F, Karger DN, Nguyen Xuan A, Mathieu J, Lavelle P, Eisenhauer N (2020) Global vulnerability of soil ecosystems to erosion. Landsc Ecol 35(4):823-842. https://doi.org/10. 1007/s10980-020-00984-z

Halmy MWA, Gessler PE, Hicke JA, Salem BB (2015) Land use/land cover change detection and prediction in the north-western coastal desert of Egypt using Markov-CA. Appl Geogr 63:101-112

Han H, Yang C, Song J (2015) Scenario simulation and the prediction of land use and land cover change in Beijing, China. Sustainability 7(4):4260-4279

Haregeweyn N, Tsunekawa A, Nyssen J, Poesen J, Tsubo M, Tsegaye Meshesha D, Schütt B, Adgo E, Tegegne F (2015) Soil erosion and conservation in Ethiopia: a review. Prog Phys Geogr 39(6):750-774

Haregeweyn N, Tsunekawa A, Poesen J, Tsubo M, Meshesha DT, Fenta A, Nyssen J, Adgo E (2017) Comprehensive assessment of soil erosion risk for better land use planning in river basins: Case study of the Upper Blue Nile River. Sci Total Environ 574:95-108

Hassen EE, Assen M (2018) Land use/cover dynamics and its drivers in Gelda catchment, Lake Tana watershed, Ethiopia. Environ Syst Res 6(1):4

Her Y, Yoo S-H, Cho J, Hwang S, Jeong J, Seong C (2019) Uncertainty in hydrological analysis of climate change: multi-parameter vs. multi-GCM ensemble predictions. Sci Rep 9(1):4974. https://doi.org/10.1038/ s41598-019-41334-7

Hishe S, Bewket W, Nyssen J, Lyimo J (2020) Analysing past land use land cover change and CA-Markov-based future modelling in the Middle Suluh Valley, Northern Ethiopia. Geocarto Int 35(3):225-255

Hu Y, Gao M (2020) Evaluations of water yield and soil erosion in the ShaanxiGansu Loess Plateau under different land use and climate change scenarios. Environ Dev 34:100488

Hurni H (1983a) Soil erosion and soil formation in agricultural ecosystems: Ethiopia and Northern Thailand. Mt Res Dev 3:131-142

Hurni H (1983b) Soil formation rates in Ethiopia: Ethiopian highland reclamation study. SCRP, Addis Ababa

Hurni H (1985) Erosion-productivity-conservation systems in Ethiopia. Conserv Product: Proc. https://doi.org/10.7892/boris.77547

Hurni K, Zeleke G, Kassie M, Tegegne B, Kassawmar T, Teferi E, Moges A, Tadesse D, Ahmed M, Degu Y (2015) Soil degradation and sustainable land management in the rainfed agricultural areas of Ethiopia: an assessment of the economic implications. Report for the Economics of Land Degradation Initiative

Ines AVM, Hansen JW (2006) Bias correction of daily GCM rainfall for crop simulation studies. Agric for Meteorol 138(1):44-53. https://doi.org/10. 1016/j.agrformet.2006.03.009

Kassie BT, Rötter RP, Hengsdijk H, Asseng S, Ittersum MKV, Kahiluoto H, Keulen HV (2014) Climate variability and change in the Central Rift Valley of Ethiopia: challenges for rainfed crop production. J Agric Sci 152(1):5874. https://doi.org/10.1017/S0021859612000986 
Khosrokhani M, Pradhan B (2014) Spatio-temporal assessment of soil erosion at Kuala Lumpur metropolitan city using remote sensing data and GIS Geomat Nat Haz Risk 5(3):252-270

Kidane M, Tolessa T, Bezie A, Kessete N, Endrias M (2019) Evaluating the impacts of climate and land use/land cover (LU/LC) dynamics on the hydrological responses of the Upper Blue Nile in the Central Highlands of Ethiopia. Spat Inf Res 27(2):151-167. https://doi.org/10.1007/ s41324-018-0222-y

Koomen E, Stillwell J (2007) Modelling land-use change. In: Modelling land-use change. Springer, Dordrecht, pp 1-22

Kouli M, Soupios P, Vallianatos F (2009) Soil erosion prediction using the Revised Universal Soil Loss Equation (RUSLE) in a GIS framework, Chania, Northwestern Crete, Greece. Environ Geol 57(3):483-497. https:// doi.org/10.1007/s00254-008-1318-9

Kura AL, Beyene DL (2020) Cellular automata Markov chain model based deforestation modelling in the pastoral and agro-pastoral areas of southern Ethiopia. Remote Sens Appl Soc Environ 18:100321

Lillesand T, Kiefer RW, Chipman J (2015) Remote sensing and image interpretation. Wiley, Hoboken

Maeda EE, Pellikka PK, Siljander M, Clark BJ (2010) Potential impacts of agricultural expansion and climate change on soil erosion in the Eastern Arc Mountains of Kenya. Geomorphology 123(3-4):279-289

Maraun D (2012) Nonstationarities of regional climate model biases in European seasonal mean temperature and precipitation sums. Geophys Res Lett 39:L06706. https://doi.org/10.1029/2012GL051210

Meinshausen M, Smith SJ, Calvin K, Daniel JS, Kainuma MLT, Lamarque J-F, Matsumoto K, Montzka SA, Raper SCB, Riahi K (2011) The RCP greenhouse gas concentrations and their extensions from 1765 to 2300. Clim Change 109(1-2):213

Melesse AM, Loukas AG, Senay G, Yitayew M (2009) Climate change, landcover dynamics and ecohydrology of the Nile River Basin. Hydrol Process Int J 23(26):3651-3652

Mengistu D, Bewket W, Lal R (2015) Soil erosion hazard under the current and potential climate change induced loss of soil organic matter in the Upper Blue Nile (Abay) River Basin, Ethiopia. In: Lal R, Singh BR, Mwaseba DL, Kraybill D, Hansen DO, Eik LO (eds) Sustainable intensification to advance food security and enhance climate resilience in Africa. Springer, Berlin, pp 137-163

Miheretu BA, Yimer AA (2018) Land use/land cover changes and their environmental implications in the Gelana sub-watershed of Northern highlands of Ethiopia. Environ Syst Res 6(1):7

Moges DM, Bhat HG (2017) Integration of geospatial technologies with RUSLE for analysis of land use/cover change impact on soil erosion: case study in Rib watershed, north-western highland Ethiopia. Environ Earth Sci 76(22):765

Mohamed A, Worku H (2020) Simulating urban land use and cover dynamics using cellular automata and Markov chain approach in Addis Ababa and the surrounding. Urban Clim 31:100545

Molla T, Sisheber B (2017) Estimating soil erosion risk and evaluating erosion control measures for soil conservation planning at Koga watershed in the highlands of Ethiopia. Solid Earth 8(1):13

Mondal MdS, Sharma N, Garg PK, Kappas M (2016) Statistical independence test and validation of CA Markov land use land cover (LULC) prediction results. Egypt J Remote Sens Space Sci 19(2):259-272. https://doi.org/ 10.1016/j.ejrs.2016.08.001

Moore ID, Burch GJ (1986a) Physical basis of the length-slope factor in the universal soil loss equation. Soil Sci Soc Am J 50(5):1294-1298

Moore ID, Burch GJ (1986b) Modelling erosion and deposition: topographic effects. Trans ASAE 29(6):1624-1630

Mullan D, Favis-Mortlock D, Fealy R (2012) Addressing key limitations associated with modelling soil erosion under the impacts of future climate change. Agric for Meteorol 156:18-30

Munthali MG, Mustak S, Adeola A, Botai J, Singh SK, Davis N (2020) Modelling land use and land cover dynamics of Dedza district of Malawi using hybrid Cellular Automata and Markov model. Remote Sens Appl Soc Environ 17:100276

Nainggolan D, Termansen M, Fleskens L, Hubacek K, Reed MS, de Vente J, Boix-Fayos C (2012) What does the future hold for semi-arid Mediterranean agro-ecosystems? - exploring cellular automata and agent-based trajectories of future land-use change. Appl Geogr 35(1-2):474-490
Nigussie TA, Fanta A, Melesse AM, Quraishi S (2014) Modeling rainfall erosivity from daily rainfall events, upper Blue Nile basin, Ethiopia. In: Melesse AM, Abtew W, Setegn SG (eds) Nile river basin. Springer, Berlin, pp 307-335

Nyssen J, Poesen J, Haile M, Moeyersons J, Deckers J, Hurni H (2009) Effects of land use and land cover on sheet and rill erosion rates in the Tigray highlands, Ethiopia. Z Geomorphol 53(2):171-197

Omrani H, Tayyebi A, Pijanowski B (2017) Integrating the multi-label land-use concept and cellular automata with the artificial neural network-based Land Transformation Model: an integrated ML-CA-LTM modeling framework. Gisci Remote Sens 54(3):283-304

Parker DC, Manson SM, Janssen MA, Hoffmann MJ, Deadman P (2003) Multiagent systems for the simulation of land-use and land-cover change: a review. Ann Assoc Am Geogr 93(2):314-337

Perović V, Kadović R, Djurdjević V, Braunović S, Čakmak D, Mitrović M, Pavlović $P$ (2019) Effects of changes in climate and land use on soil erosion: a case study of the Vranjska Valley, Serbia. Reg Environ Change 19(4):1035-1046

Plangoen P, Babel MS, Clemente RS, Shrestha S, Tripathi NK (2013) Simulating the impact of future land use and climate change on soil erosion and deposition in the Mae Nam Nan sub-catchment Thailand. Sustainability 5(8):3244-3274

Pontius RG Jr (2002) Statistical methods to partition effects of quantity and location during comparison of categorical maps at multiple resolutions. Photogramm Eng Remote Sens 68(10):1041-1050

Ralha CG, Abreu CG, Coelho CG, Zaghetto A, Macchiavello B, Machado RB (2013) A multi-agent model system for land-use change simulation. Environ Model Softw 42:30-46

Renard KG, Freimund JR (1994) Using monthly precipitation data to estimate the R-factor in the revised USLE. J Hydrol 157(1):287-306. https://doi. org/10.1016/0022-1694(94)90110-4

Renard KG (1997) Predicting soil erosion by water: a guide to conservation planning with the Revised Universal Soil Loss Equation (RUSLE). United States Government Printing

Reshmidevi TV, Eldho TI, Jana R (2009) A GIS-integrated fuzzy rule-based inference system for land suitability evaluation in agricultural watersheds. Agric Syst 101(1):101-109. https://doi.org/10.1016/j.agsy.2009.04.001

Routschek A, Schmidt J, Kreienkamp F (2014) Impact of climate change on soil erosion - a high-resolution projection on catchment scale until 2100 in Saxony/Germany. Catena 121:99-109

Sang L, Zhang C, Yang J, Zhu D, Yun W (2011) Simulation of land use spatial pattern of towns and villages based on CA-Markov model. Math Comput Model 54(3-4):938-943. https://doi.org/10.1016/j.mcm.2010.11.019

Serpa D, Nunes JP, Santos J, Sampaio E, Jacinto R, Veiga S, Lima JC, Moreira M, Corte-Real J, Keizer JJ (2015) Impacts of climate and land use changes on the hydrological and erosion processes of two contrasting Mediterranean catchments. Sci Total Environ 538:64-77

Shamir E, Megdal SB, Carrillo C, Castro CL, Chang H-I, Chief K, Corkhill FE, Eden S, Georgakakos KP, Nelson KM (2015) Climate change and water resources management in the Upper Santa Cruz River, Arizona. J Hydrol 521:18-33

Sharma A, Tiwari KN, Bhadoria PBS (2011) Effect of land use land cover change on soil erosion potential in an agricultural watershed. Environ Monit Assess 173(1-4):789-801

Shrestha M (2015) Data analysis relied on linear scaling bias correction (V. 1.0) Microsoft Excel File

Simane B, Zaitchik BF, Ozdogan M (2013) Agroecosystem analysis of the Choke Mountain watersheds, Ethiopia. Sustainability 5(2):592-616

Singh SK, Mustak S, Srivastava PK, Szabó S, Islam T (2015) Predicting spatial and decadal LULC changes through cellular automata Markov chain models using earth observation datasets and geo-information. Environ Process 2(1):61-78

Sisay K, Thurnher C, Hasenauer H (2017) Daily climate data for the Amhara region in Northwestern Ethiopia. Int J Climatol 37(6):2797-2808

Srivastava PK, Han D, Rico-Ramirez MA, Islam T (2014) Sensitivity and uncertainty analysis of mesoscale model downscaled hydro-meteorological variables for discharge prediction. Hydrol Process 28(15):4419-4432

Steenhuis TS, Easton ZM, Awulachew SB, Ahmed AA, Bashar KE, Adgo E, Selassie YG, Tilahun SA (2013) The Nile Basin sediment loss and degradation, with emphasis on the Blue Nile. In: The Nile River Basin, Routledge, pp 134-154 
Streile G, Shields KD, Stroh JL, Bagaasen LM, Whelan G, McDonald JP, Droppo JG, Buck JW (1996) The multimedia environmental pollutant assessment system. Pacific Northwest National Lab, Richland

Sun W, Shao Q, Liu J (2013) Soil erosion and its response to the changes of precipitation and vegetation cover on the Loess Plateau. J Geogr Sci 23(6):1091-1106

Tadesse L, Suryabhagavan KV, Sridhar G, Legesse G (2017) Land use and land cover changes and Soil erosion in Yezat Watershed, North Western Ethiopia. Int Soil Water Conserv Res 5(2):85-94

Tamene L, Le QB (2015) Estimating soil erosion in sub-Saharan Africa based on landscape similarity mapping and using the revised universal soil loss equation (RUSLE). Nutr Cycl Agroecosyst 102(1):17-31

Tamene L, Vlek PL (2008) Soil erosion studies in northern Ethiopia. In: Braimoh AK, Vlek PLG (eds) Land use and soil resources. Springer, Berlin, pp 73-100

Taye G, Vanmaercke M, Poesen J, Van Wesemael B, Tesfaye S, Teka D, Nyssen J, Deckers J, Haregeweyn N (2018) Determining RUSLE P- and C-factors for stone bunds and trenches in rangeland and cropland North Ethiopia. Land Degrad Dev 29(3):812-824

Teferi E, Bewket W, Uhlenbrook S, Wenninger J (2013) Understanding recent land use and land cover dynamics in the source region of the Upper Blue Nile, Ethiopia: spatially explicit statistical modeling of systematic transitions. Agric Ecosyst Environ 165:98-117

Teklesadik AD, Alemayehu T, Van Griensven A, Kumar R, Liersch S, Eisner S, Tecklenburg J, Ewunte S, Wang X (2017) Inter-model comparison of hydrological impacts of climate change on the Upper Blue Nile basin using ensemble of hydrological models and global climate models. Clim Change 141(3):517-532

Teutschbein C, Seibert J (2010) Regional climate models for hydrological impact studies at the catchment scale: a review of recent modeling strategies. Geogr Compass 4(7):834-860

Teutschbein C, Seibert J (2012) Bias correction of regional climate model simulations for hydrological climate-change impact studies: Review and evaluation of different methods. J Hydrol 456:12-29

Thomson AM, Calvin KV, Smith SJ, Kyle GP, Volke A, Patel P, Delgado-Arias S, Bond-Lamberty B, Wise MA, Clarke LE (2011) RCP4. 5: a pathway for stabilization of radiative forcing by 2100. Clim Change 109(1-2):77

van Vuuren DP, Edmonds J, Kainuma M, Riahi K, Thomson A, Hibbard K, Hurtt GC, Kram T, Krey V, Lamarque J-F, Masui T, Meinshausen M, Nakicenovic N, Smith SJ, Rose SK (2011) The representative concentration pathways: an overview. Clim Change 109(1):5. https://doi.org/10.1007/ s10584-011-0148-z

Veldkamp A, Lambin EF (2001) Predicting land-use change. Agric Ecosyst Environ 85(1):1-6. https://doi.org/10.1016/S0167-8809(01)00199-2

Verburg PH, Schot PP, Dijst MJ, Veldkamp A (2004) Land use change modelling: Current practice and research priorities. GeoJournal 61 (4):309-324

Wagena MB, Sommerlot A, Abiy AZ, Collick AS, Langan S, Fuka DR, Easton ZM (2016) Climate change in the Blue Nile Basin Ethiopia: implications for water resources and sediment transport. Clim Change 139(2):229-243

Weber EU (2006) Experience-based and description-based perceptions of long-term risk: why global warming does not scare us (yet). Clim Change 77(1-2):103-120
Wijtkosum S (2012) Impacts of land use changes on soil erosion in Pa Deng sub-district, adjacent area of Kaeng Krachan National Park, Tailand. Soil Water Res 7(1):10-17

Wischmeier WH, Smith DD (1978) Predicting rainfall erosion losses. Agricultural handbook 537. Agricultural Research Service, United States Department of Agriculture

Wischmeier WH, Johnson CB, Cross BV (1971) Soil erodibility nomograph for farmland and construction sites. https://trid.trb.org/view/125184

Woldesenbet TA, Elagib NA, Ribbe L, Heinrich J (2018) Catchment response to climate and land use changes in the Upper Blue Nile sub-basins, Ethiopia. Sci Total Environ 644:193-206

Worku G, Teferi E, Bantider A, Dile YT, Taye MT (2018) Evaluation of regional climate models performance in simulating rainfall climatology of Jemma sub-basin, Upper Blue Nile Basin, Ethiopia. Dyn Atmos Oceans 83:53-63

Woznicki SA, Nejadhashemi AP, Tang Y, Wang L (2016) Large-scale climate change vulnerability assessment of stream health. Ecol Ind 69:578-594

Wubie MA, Assen M, Nicolau MD (2016) Patterns, causes and consequences of land use/cover dynamics in the Gumara watershed of lake Tana basin, Northwestern Ethiopia. Environ Syst Res 5(1):8

Xie Y, Batty M, Zhao K (2007) Simulating emergent urban form using agentbased modeling: Desakota in the Suzhou-Wuxian region in China. Ann Assoc Am Geogr 97(3):477-495

Yaekob T, Tamene L, Gebrehiwot SG, Demissie SS, Adimassu Z, Woldearegay K, Mekonnen K, Amede T, Abera W, Recha JW (2020) Assessing the impacts of different land uses and soil and water conservation interventions on runoff and sediment yield at different scales in the central highlands of Ethiopia. Renew Agric Food Syst. https://doi.org/10.1017/ S1742170520000010

Yalew S, Mul ML, Van Griensven A, Teferi E, Priess J, Schweitzer C, van Der Zaag P (2016) Land-use change modelling in the Upper Blue Nile Basin. Environments 3(3):21

Yang X, Zheng X-Q, Chen R (2014) A land use change model: Integrating landscape pattern indexes and Markov-CA. Ecol Model 283:1-7

Yesuph AY, Dagnaw AB (2019) Soil erosion mapping and severity analysis based on RUSLE model and local perception in the Beshillo Catchment of the Blue Nile Basin, Ethiopia. Environ Syst Res 8(1):17

Zabihi H, Ahmad A, Vogeler I, Said MN, Golmohammadi M, Golein B, Nilashi M (2015) Land suitability procedure for sustainable citrus planning using the application of the analytical network process approach and GIS. Comput Electron Agric 117:114-126. https://doi.org/10.1016/j.compag. 2015.07.014

Zhang XC, Nearing MA (2005) Impact of climate change on soil erosion, runoff, and wheat productivity in central Oklahoma. Catena 61(2):185-195. https://doi.org/10.1016/j.catena.2005.03.009

Zhou P, Luukkanen O, Tokola T, Nieminen J (2008) Effect of vegetation cover on soil erosion in a mountainous watershed. Catena 75(3):319-325. https://doi.org/10.1016/j.catena.2008.07.010

\section{Publisher's Note}

Springer Nature remains neutral with regard to jurisdictional claims in published maps and institutional affiliations.

\section{Submit your manuscript to a SpringerOpen ${ }^{\circ}$ journal and benefit from:}

- Convenient online submission

- Rigorous peer review

- Open access: articles freely available online

- High visibility within the field

Retaining the copyright to your article

Submit your next manuscript at $\boldsymbol{\nabla}$ springeropen.com 